\title{
DOSSIÊ
}

\section{Tradição e autenticidade em um mundo pós-convencional: uma leitura durkheimiana'}

\begin{abstract}
${ }^{1}$ Os temas abordados aqui refletem o trabalho de pesquisa sobre a teoria durkheimiana, realizada pelos autores por mais de 14 anos, em diferentes trajetórias. O trabalho de Rosati esteve centrado sobre o tema da religião, enquanto Weiss dedicou-se especificamente à moral. As distintas tarjetórias finalmente se cruzaram, em outubro de 2012, durante a celebração do centenário da publicação de "Les Formes Elementaires de la Vie Religieuse", de Durkheim, em Porto Alegre. Era o início de uma amizade profunda, que começou com a promessa de trabalhar juntos no futuro. A oportunidade surgiu com a organização deste dossier e a escrita deste artigo, cuja preparação começou em novembro de 2013, como o primeiro de uma longa lista de projetos que pretendíamos realizar juntos. No mês seguinte, iniciamos um intenso diálogo que resultou no esboço geral do artigo. Infelizmente, em 30 de janeiro de 2014, Massimo Rosati nos deixou, aos 44 anos. Finalizar sozinha um trabalho iniciado em cooperação pareceu um desafio quase insuperável, especialmente por saber que nunca seria o mesmo que se escrito em conjunto, porque - como disse Durkheim - um grupo é sempre algo qualitativamente diferente da soma dos indivíduos que o compõe, uma vez que a interação cria algo completamente novo. Este trabalho, portanto, representa o esforço máximo de honrar a memória de Rosati e nossa parceria intelectual, recriando cada ideia discutida entre nós. Também tentei incluir de forma coerente cada fragmento textual escrito por Rosati como parte do manuscrito. Qualquer imprecisão, no entanto, é de minha total responsabilidade. Finalmente, agradeço, entre outros, a Alessandro Ferrara, que me ajudou ao longo de todo o caminho, fornecendo referências ausentes, discutindo ideias de Rosati, com uma profundidade que só uma amizade que durou mais de 20 anos permitiria, e revisando o manuscrito, a fim de me tranquilizar de que nenhuma sentença estaria em contradição com seus pressupostos teóricos.

* Universidade de Roma (Itália)

** Universidade Federal do Rio Grande do Sul (Brasil)
\end{abstract}




\section{Resumo}

Neste artigo pretendemos demonstrar por que a teoria durkheimiana ainda é relevante para os debates contemporâneos sobre moral e como a sociologia poderia lidar com a mesma. De certa forma, é um esforço para estabelecer as bases do que seria, hoje, uma sociologia durkheimiana da moral ou, melhor, de como poderíamos conceber uma sociologia contemporânea da moral de inspiração durkheimiana. Para isso, vamos primeiramente reconstruir os elementos ontológicos implícitos à sua visão da moral, destacando uma dimensão que é precisamente a que essa teoria é acusada de negligenciar: uma discussão sobre a natureza humana e as condições para a constituição do eu. Em um segundo movimento, apresentamos algumas considerações "operacionais" sobre o que esta sociologia durkheimiana da moral poderia ser hoje, apontando para o nível de análise com que ela pode lidar, para o que ela pode pretender explicar e - por que não? (acrescentando um toque weberiano) - entender. A etapa final nos leva ao território de uma teoria social normativa, que consiste em uma discussão crítica de moralidades patológicas, do ponto de vista do sofrimento que elas podem infligir ao indivíduo, e dos desafios trazidos pela modernidade tardia, caracterizada por uma multiplicidade de objetos sagrados que habitam o mesmo espaço.

Palavras-chave: Sociologia moral. Moral e religião. Sagrado. Self.

\section{Tradition and Authenticity in Post-Conventional World:}

\section{a Durkheimian Reading}

\section{Abstract}

In this paper we intend to demonstrate why Durkheimian theory is still relevant to contemporary debates on morality and on how sociology could deal with it. In a way, it is an effort to establish the basis of what could be a Durkheimian sociology of morality today or, even better, how we can conceive a contemporary sociology of morality with Durkheimian inspiration. For this purpose, we will first

•Tradução: Carolina Fernandes 
Sociologias, Porto Alegre, ano 17, no 39, mai/ago 2015, p. 110-162

reconstruct the ontological elements implied in his view of morality, highlighting a dimension that is precisely the one this theory is blamed for neglecting: a discussion about human nature and the conditions for constituting of the self. In a second movement, we present a few 'operational' considerations on what this Durkheimian sociology of morality could be today, pointing to the level of analysis it can deal with, to what it can aim to explain and - why not? (introducing a Weberian flavour) - understand. The final step leads us to the territory of a normative social theory, consisting in a critical discussion of pathological moralities, from the point of view of the suffering they can bring to the individual, and of the challenges brought by late modernity, characterized by a multiplicity of sacred objects inhabiting the same space.

Key words: Sociology of morality. Morality and religion. Sacred. Self.

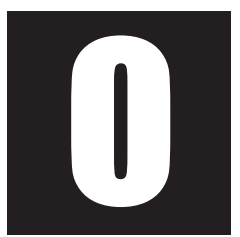

interesse sociológico pela moral remonta às próprias origens da disciplina e se manifesta de forma especialmente visível na sociologia durkheimiana. A moral esteve presente no cerne da obra de Durkheim já em seus primeiros trabalhos (DURKHEIM, 1887b; 1893) e, até certo ponto, seu projeto de uma sociologia da moral quase se poderia confundir com sua própria concepção de sociologia Isso, provavelmente, poderia ser explicado pela profunda influência kantiana, tão essencial na formulação de sua abordagem do mundo social; um kantismo interpretado pela ótica de Renouvier. Não seria exagero dizer que a moral continuou sendo o principal objetivo das investigações de Durkheim e - essa é uma das teses que trazemos aqui - suas contribuições ao debate sobre a moralidade são muito mais profundas e mais extensas do que as explicitadas em seus trabalhos especificamente relacionados à "sociologia da moral".

Assim, neste artigo, vamos explicitar por que consideramos a teoria durkheimiana tão relevante para os debates contemporâneos sobre a moral e para apontar como a sociologia poderia lidar com a mesma. De 
Sociologias, Porto Alegre, ano 17, no 39, mai/ago 2015, p. 110-162

certa forma, este é um esforço para estabelecer as bases do que seria, hoje, uma sociologia da moral durkheimiana; ou melhor, para conceber uma sociologia da moral contemporânea, de inspiração durkheimiana, depurando o projeto de Durkheim daquilo que consideramos mais problemático e destacando as ideias cruciais para a compreensão da moral como um fenômeno social e para a reflexão crítica sobre este aspecto essencial da vida humana.

Nossa análise pretende centrar-se nos "interstícios" da obra de Durkheim, ou seja, nos significados que emergem, não de modo explícito, literal, mas que podem ser inferidos no esforço contemporâneo de captar seu espírito - as ideias que fluem da interpretação de um projeto inacabado, muito mais ambicioso do que sugere a interpretação canônica. Assim, essa é uma tentativa de fazer brotarem sementes plantadas em solo fértil, mas que foram recobertas pela poeira e pedras da história antes que pudessem germinar. É notório que o livro inacabado de Durkheim, "La Morale" ${ }^{\prime 2}$, teria sido sua obra-prima, reunindo textos sobre política, religião e educação, de modo a oferecer uma explanação renovada daquilo que foi seu principal objeto de interesse desde os primeiros textos: a moral.

Portanto, nosso intento - que talvez possa soar algo ultrapassado e deslocado para aqueles que já condenaram a sociologia durkheimiana da moral ao "museu de antiguidades" - é escavar entre as rochas de (más) interpretações consolidadas, para descobrir as sementes que, acreditamos, podem desabrochar no debate contemporâneo como um projeto renovado de uma sociologia da moral inspirada na teoria de Durkheim. Para tanto, nossa argumentação segue um caminho duplamente entrecru-

${ }^{2}$ Deste projeto temos apenas a introdução e o índice, editados e publicados postumamente por Mauss (DURKHEIM, 1920). O possível projeto do livro pode ser parcialmente reconstruído na medida em que o índice faz menção a manuscritos preparados para aulas ministradas no decorrer de sua carreira. 
Sociologias, Porto Alegre, ano 17, no 39, mai/ago 2015, p. 110-162

zado: o dos textos, a partir dos quais tentamos reconstruir os argumentos de Durkheim que melhor expressam as ideias do autor; e o do espírito, pelo qual tentamos compreender seu raciocínio e aplicá-lo a realidades, problemas e dilemas que não existiam em sua época. Nosso propósito é atualizar sua teoria para possibilitar o diálogo com debates e realidades contemporâneos.

Tendo em vista este propósito, primeiramente reconstruiremos os elementos ontológicos implícitos à sua visão da moral, destacando uma dimensão que é precisamente a que sua teoria é acusada de negligenciar: o debate sobre a natureza humana e as condições para a constituição do self. Em um segundo movimento, apresentaremos algumas considerações "operacionais" sobre o que seria, hoje, essa sociologia durkheimiana da moral, sinalizando o nível de análise com que ela poderia lidar, o que ela pode pretender explicar e - porque não? (introduzindo um toque weberiano) compreender. A etapa final conduz-nos ao território de uma teoria social normativa, que consiste na discussão crítica de moralidades patológicas, sob o ponto de vista do sofrimento que elas podem causar ao indivíduo e dos desafios trazidos pela modernidade tardia, caracterizada por uma multiplicidade de objetos sagrados habitando um mesmo espaço.

\section{Premissa ontológica: a Moral como um fenômeno religioso}

A moral foi um tema crucial dos interesses de Durkheim durante toda sua vida e há vários modos de abordar este universo. Um deles é, indubitavelmente, através do debate com tradições filosóficas, tais como o utilitarismo e o kantismo, uma tese extensamente desenvolvida por nós e por outros autores (HALL, 1987; LACAPRA, 1972; MILLER, 1996; WEISS, 2006). O mesmo se aplica à relação intrínseca entre moral e educação (CARDI et al., 1993; WILSON; SCHNURER, 1973; ISAMBERT-JAMATI, 
Sociologias, Porto Alegre, ano 17, no 39, mai/ago 2015, p. 110-162

2001; WEISS, 2009). Partindo dessas análises, pretendemos abordar tal questão por um ângulo diferente, plenamente consistente com o espírito da obra durkheimiana e que também está explícito em seus textos. Tal ângulo também apresenta uma importante vantagem analítica, ou seja, permite lançar luz sobre esse fenômeno, incorporando importantes elementos desenvolvidos na fase mais tardia de sua carreira, quando sua teoria adquire uma sofisticação mais profunda.

Nossa porta de entrada é a relação intrínseca entre moral e religião; por isso, examinaremos um conjunto de textos focados nessas duas questões, interpretando-os de forma inter-relacionada. Os argumentos aqui apresentados resultam de pesquisas realizadas pelos autores ao longo dos últimos quatorze anos. Por essa razão, ao invés de uma análise detalhada de cada texto, estruturamos um panorama geral, descrevendo os argumentos que consideramos mais relevantes, para proporcionar uma compreensão renovada da concepção durkheimiana de moral e tópicos correlatos. Nossas principais fontes são os livros "Le Suicide" (DURKHEIM, 1897a), "L'Éducation Morale" (DURKHEIM, 1925a), "Sociologie et Philosophie" (DURKHEIM, 1924a) e "Les Formes Élementaires de la Vie Réligieuse", bem como os artigos sobre moral (DURKHEIM, 1887b, 1898, 1905, 1908, 1920, 2007) e religião (DURKHEIM, 1887a, 1913, 1914).

\subsection{Os aspectos formais do fato moral}

Podemos encontrar referência à relação intrínseca entre moral e religião em dois dos textos mais importantes de Durkheim sobre moralidade (DURKHEIM, 1925, 1992). Nesses, ele afirma que, para determinar os elementos formais que caracterizam a moral, devemos investigar a religião, pois por um longo período e em todas as culturas, a moral sempre existiu sob a forma religiosa. Sua análise indicou dois elementos básicos, sem os quais não poderíamos sequer falar sobre moral. São eles: o dever e o bem. 
Sociologias, Porto Alegre, ano 17, no 39, mai/ago 2015, p. 110-162

Esses dois elementos devem ser intrínsecos a qualquer sistema moral, seja religioso ou secular, e a diferenciação entre eles deve fundar-se em um terceiro elemento - igualmente formal -, a racionalidade, compreendida como o reconhecimento de que a moral não possui uma fonte transcendente, logo, pode ser conhecida e transformada, de acordo com princípios racionalmente aceitos. De certa forma, esta hipótese básica acarreta consequências profundas, tanto para compreender a sociedade e o ego, quanto para estabelecer um possível campo de investigação para uma sociologia da moral e lidar com patologias e dilemas contemporâneos.

Durkheim considera o dever como o aspecto mais externo de qualquer fato moral, uma vez que, em quase todas as circunstâncias, a moralidade toma a forma de um imperativo, uma regra. Aquilo que é moral, é obrigatório, não é opcional. É o que um indivíduo precisa fazer em uma circunstância específica; é um "dever". Isso tem importância metodológica, já que identificar determinado fato como moral pressupõe reconhecer nele tal imperativo. Vejamos como exemplo a ideia de que não devemos matar outra pessoa: esta regra social nos diz que independentemente do tipo de sentimento que alimentemos por outras pessoas, não podemos cometer assassinato. Não há possibilidade de escolha e desacatar este mandamento implica sanção não apenas moral, mas também legal. Essa regra moral deve ser seguida por todos que pertencem ao grupo social e se mostrará aos indivíduos como um imperativo, já que não foi criada por eles. Além disso, é um princípio aplicável a todas as circunstâncias, independentemente dos sentimentos e ideias da pessoa em um momento específico.

A raison d être para a moral ser uma regra, e não uma sugestão ou opção, é que ela precisa criar um mundo comum para indivíduos pertencentes a uma mesma comunidade, estabelecendo padrões e limites para suas ações. Uma segunda noção relacionada a este aspecto da moral como um dever é a da autoridade, no sentido de que o princípio moral é

http://dx.doi.org/10.1590/15174522-017003904 
Sociologias, Porto Alegre, ano 17, no 39, mai/ago 2015, p. 110-162

uma ideia que instila respeito, uma característica diretamente relacionada à origem da comunidade. De certa forma, a legitimidade de determinada regra depende do reconhecimento de sua origem, um ponto que detalharemos nas duas próximas seções.

O segundo elemento, o bem, é apresentado de modo a estabelecer um contraponto à filosofia kantiana, enfatizando que a moral nunca é puramente uma obrigação. Para Durkheim, não somos puramente razão; assim, uma moral Kantiana seria uma moral para anjos, não para seres humanos, pois agimos apenas quando sentimos algo - se somos compelidos a fazê-lo, seja por medo ou por atração. Como uma ação por medo da punição está excluída da definição de moral, supõe-se que um princípio moral deva ser desejado pelo indivíduo, considerado algo bom e certo. Nesse sentido, um princípio moral expressa, mais que um mandamento, uma ideia persuasiva para o indivíduo, por acreditar que seguir a regra é também fazer a coisa certa, é fazer o bem. Seguindo com o mesmo exemplo, o mandamento de não matar outra pessoa não é uma regra qualquer, ou uma que sigo por conveniência, mas algo que considero correto por prescrever uma conduta que aprovo. Isso ocorre, porque no cerne da moral existem os "ideais", dos quais as regras são apenas o aspecto mais externo. O significado pleno desse conceito de ideal se tornará mais evidente nos últimos textos de Durkheim, e sua compreensão depende de um novo marco conceitual apresentado no contexto de seus textos sobre religião. Contudo, antes de tratar deles, ainda precisamos apresentar brevemente o terceiro elemento, a racionalidade, que deverá ser a característica distintiva de uma moral racional.

A ideia de racionalidade, aqui, deve ser entendida como o que Miller $(1996,2009)$ chama de o ideal de transparência, a hipótese de que uma moralidade não religiosa pode ser plenamente transparente para seus membros, os quais, uma vez conhecendo suas origens e sua raison 
Sociologias, Porto Alegre, ano 17, no 39, mai/ago 2015, p. 110-162

d 'être, podem aceitar de forma esclarecida seus valores e regras. Basicamente, é uma situação ideal, que corresponderia ao ápice do projeto moderno de estabelecer uma moralidade sem deus, uma tradição baseada naquilo que poderíamos chamar de uma "tradição racional". No exemplo que estamos examinando, uma ação moral autônoma consistiria em não cometer assassinato porque o indivíduo acredita que isto não é correto, pois sente que a vida humana é um valor e conhece a origem dessa regra e seu ideal moral: ele pode "enunciar as razões" para agir assim, explicar porque isso é um mandamento e porque o considera algo bom. Em seu nível mais profundo, isso significaria que o indivíduo sabe que essa é uma noção socialmente estabelecida e a respeita por isso mesmo.

Mas, como já colocamos, para Durkheim, o aspecto coercivo é constitutivo da moral, e é necessário para garantir a vida social. Contudo, há um problema evidente nesta concepção formal de dever, trazido pela ideia de autonomia como adesão esclarecida a uma tradição moral. Para compreender plenamente essas implicações, vale abordar os desenvolvimentos posteriores do pensamento de Durkheim, que trouxeram a questão das crenças morais - os ideais - para um nível de complexidade totalmente novo, afirmando que cada crença sugere uma dimensão afetiva, emocional, que extrapola o nível racional. Por essa razão, a discussão sobre crença, sagrado, ritual, efervescência - central para sua sociologia da religião - traz uma série de novas interpretações para sua concepção da moral. Então, resta a questão: como pode uma moral secular ser, ao mesmo tempo, autônoma e sagrada, o que significa ser esclarecida e auto-reflexiva e simultaneamente reconhecer que cada ideal moral é uma criação coletiva. Esta será a questão central a ser abordada na seção final, ao discutirmos suas implicações normativas. 
Sociologias, Porto Alegre, ano 17, no 39, mai/ago 2015, p. 110-162

\subsection{Como a sociologia da religião ajuda a compreender a moral}

Até agora, apresentamos o dever e o bem como sendo dois aspectos mandatórios de qualquer princípio, ou fato, os quais se possam considerar morais. Isso sugere que o fenômeno moral pode configurar-se duplamente: como regra e como um ideal. Sob uma perspectiva genealógica, o ideal tem prioridade sobre a regra, por ser a expressão daquilo que é considerado mais importante para determinada comunidade; e a regra é um tipo de mecanismo regulatório, que visa garantir que nossas ações não desrespeitem este ideal. Outro ponto que vale mencionar é que tanto as regras quanto os ideais têm dupla dimensão: emocional, relacionada com nossa faculdade de sentir dor e prazer, tocando diretamente nossos sentimentos; e cognitivo, no sentido de que são representações mentais. O dever é uma regra - certa representação que informa de modo imperativo o certo a fazer - na qual reconhecemos autoridade moral de impor obrigação, não apenas racionalmente, mas também emocionalmente, instaurando sentimentos de controle, restrição, proibição, medo e respeito. O bem, por sua vez, é também uma representação mental, pois corresponde a ideias sobre um estado de coisas consideradas certas, desejadas, justas e corretas, que fazem sentido sob um ponto de vista argumentativo, que pode ser representado em nossa imaginação. Mas, além do fato de fazerem sentido e poderem ser logicamente justificadas, também tocam nossas emoções, provocando sentimentos como atração, adesão, identificação, felicidade, prazer e - um compartilhado com a obrigação - respeito.

${ }^{3}$ Ministradas por volta de 1902 e em uma aula para estudantes em Auteuil (1992a), provavelmente ministrada em 1908-9. 
Sociologias, Porto Alegre, ano 17, no 39, mai/ago 2015, p. 110-162

Por isso, podemos dizer que respeito é a emoção chave, pois tem relação tanto com o dever quanto com o bem, e é o elemento constitutivo de qualquer regra moral e ideal moral. Elemento já presente nos manuscritos redigidos para suas aulas sobre a educação moral $(1925 a)^{3}$,esse sentimento de respeito, segundo Durkheim, é mais bem compreendido quando pensamos na relação de um crente com seu deus, considerado a fonte da autoridade que pode tanto punir o transgressor quanto proporcionar conforto e segurança - uma combinação de medo e amor. Essa não é exatamente uma boa metáfora, mas ajuda a preparar o terreno para introduzir o conceito de sagrado, que é crucial para entender não apenas regras e ideais, mas também a própria ideia de deus, já que tal conceito é o cerne de sua definição de religião: um conjunto de ideias sagradas as crenças - e de práticas sagradas - os ritos. Como veremos, essa ideia deve ser considerada o ponto fulcral da moralidade, se quisermos explorar todo o potencial implícito numa sociologia da moral durkheimiana. Nessa perspectiva, o sagrado desempenha um papel determinante em nossos julgamentos morais e se poderia inclusive afirmar que a diferença entre o sagrado e o profano é a base de nossas categorias de certo e errado. O "bem", o sagrado [faste] refere-se ao que é moralmente bom, moralmente aprovado, enquanto o "mal" sagrado [néfaste] é associado ao mau, ao moralmente errado. O profano é o que é moralmente neutro, mas que jamais pode desacatar ou tocar o sagrado. No exemplo que estamos usando, a vida humana é considerada o bem sagrado, aquilo que valorizamos acima de tudo. Um assassinato é o mal absoluto, está além da vida mundana e provoca sentimentos profundos de horror e desaprovação. Em comparação, o universo da economia e do mercado, por exemplo, poderia ser considerado o mundo do profano e, enquanto estivesse em seu lugar, permaneceria moralmente neutro. Mas, não se pode tentar estabelecer um preço para os seres humanos ou comercializá-los,

http://dx.doi.org/10.1590/15174522-017003904 
Sociologias, Porto Alegre, ano 17, no 39, mai/ago 2015, p. 110-162

pois isso seria a profanação de algo sagrado, seria uma tentativa de medir o incomensurável, tornando-se objeto de sanções morais.

O sagrado é a ideia mais importante no livro "Les Formes Elementaires" e, ainda assim, não é conceitualmente definido (PICKERING, 2009). Entretanto, é possível compreender seu significado coletando várias referências identificadas ao longo do texto, que permitem definir o sagrado como uma "propriedade" ligada a coisas, práticas, ideias e indivíduos, a qual nos faz pensar serem essas dotadas de um caráter excepcional, que não questionamos, não tocamos, que as torna distintas no mundo (WEISS, 2013b). O ponto principal sobre essa propriedade é que ela pertence a outro mundo, de forma a nunca estar plenamente disponível, sempre envolta em uma aura que lhe confere uma dimensão transcendental, e também heterônoma, tornando-a uma fonte de obrigação, acima de qualquer negociação possível, como aconteceria em uma lógica utilitarista (ROSATI, 2009, p. 76).

Resumidamente, o dever é assim percebido, porque as regras morais são regras sagradas e o bem é desejado por constituir um conjunto de valores sagrados. Sob o ponto de vista sociológico, é necessário investigar a fundo para compreender por que as coisas se tornam sagradas, supondo-se não ser esta uma característica inerente. Para apresentar breve e simplificadamente uma argumentação que é deveras complicada ${ }^{4}$, o processo envolvido aqui pode ser considerado uma consagração, o resultado final de um processo dinamogênico, desencadeado pela efervescência coletiva, a dimensão empírica mais crucial da vida humana - conforme nossa interpretação da teoria durkheimiana. Dinamogenia é um processo de intensificação da energia experimentada pelos indivíduos, naquelas

"Para uma discussãoo mais detalhada sobre este tema, ver Pickering (2009), Rappaport (1999), Rosati (2005; 2009) e Weiss ( 2012, 2013a, 2013b) 
Sociologias, Porto Alegre, ano 17, no 39, mai/ago 2015, p. 110-162

circunstâncias excepcionais em que pensam e agem juntos, provocando um estado efusivo, que libera sentimentos e emoções intensos, um senso de pertencimento a uma realidade maior, uma força mais poderosa do que a de cada um, fazendo aquela circunstância parecer verdadeiramente excepcional (MILLER, 2005; TIRYAKIAN, 2009; WEISS, 2012). O contraste entre esses momentos extraordinários e a vida cotidiana cria a impressão de que tudo o que pertence àquela vida coletiva é dotado de uma excepcionalidade indiscutível, e é esse sentimento que associamos às pessoas, objetos e ideias que consideramos assim nesse momento de intensa interação coletiva. Para nosso foco de interesse aqui, o argumento importante subjacente a esta explanação é que o ideal, considerado o cerne e a alma de toda moral, precisa ser algo criado pela coletividade em momentos de interação social, na medida em que ele só se torna um ideal moral após passar pelo processo de consagração coletiva. Nesse sentido, um ideal moral nunca é uma crença individual, é sempre uma representação coletiva, internalizada pelo indivíduo e dotada de um status sagrado, e qualquer objeção a esta crença ou conjunto de crenças implica sanções por parte do grupo.

Disso decorre que a moral, como conjunto de regras sagradas e valores sagrados, assemelha-se muito à religião e, a isto, deveríamos acrescentar outro elemento, o ritual, compreendido como um conjunto de práticas que têm a propriedade de produzir momentos de efervescência, os quais, por sua vez, são condição sine qua non na criação e recriação do sagrado. Um ritual normalmente envolve certo número de práticas pré-estabelecidas, com funções específicas dos participantes e um conjunto de símbolos, que podem servir tanto à dimensão cognitiva como à emocional, à obrigação e ao bem. Mas é sempre uma força que se sobrepõe às emoções individuais, reprimindo-as ou as realçando. O ritual, juntamente com o sagrado, é o fenômeno mais evidente da vida religiosa, 
Sociologias, Porto Alegre, ano 17, no 39, mai/ago 2015, p. 110-162

o que explica a existência de tantos trabalhos teóricos e empíricos sobre religião dentro da antropologia e da sociologia ${ }^{5}$. Trazer esta discussão para o campo da sociologia da moral é um processo crucial, não apenas por ser uma fonte de efervescência, mas também devido à sua função simbólica.

O ritual também tem o poder de produzir significados compartilhados, uma vez que atuar de maneira ritualista também é atuar conforme um "como se", é criar um campo de significados, como Schütz o chamaria; ele tem o poder de tornar quase reais pensamentos e sonhos que, de outra maneira, permaneceriam confinados ao nível da consciência individual. O mesmo vale para os mitos e símbolos cultivados num ritual: as práticas compartilhadas tornam o símbolo sagrado e, assim, a ideia, pessoa ou objeto que passa a incorporar os ideais do grupo torna-se uma representação coletiva, capaz de promover a solidariedade até mesmo quando a efervescência desaparece, pois é uma lembrança daqueles momentos de grandeza (COLLINS, 2014; ROSATI, 2009, p. 47). Como um exemplo simples, podemos pensar na bandeira francesa. Ela não é apenas um pedaço de tecido - representa o momento original da extraordinária efervescência produzida por ocasião da Revolução Francesa e dos rituais subsequentes, celebrando a République e seus ideais. Assim, mesmo na vida cotidiana, a bandeira permanece como símbolo sagrado de tudo aquilo. Tanto rituais quanto símbolos são particularmente relevantes na

\footnotetext{
${ }^{5}$ Uma discussão mais completa das múltiplas formas de ação coletiva e dos diferentes tipos de ritos está detalhada em outro trabalho (ROSATI, 2009, cap. 3) e tem como base teórica uma reinterpretação sistemática das principais análises sobre o tema do ritual e da performance, a maior parte da quais pode ser considerada como distintos desenvolvimentos da sociologia durkheimiana da religião (ALEXANDER, 1990, 2013; ALEXANDER; GIESEN; MAST, 2006; COLLINS, 2014; RAPPAPORT, 1999) ou, até de diferentes tradições (SELIGMAN, 2009; SELIGMAN et al., 2008; SELIGMAN; WELLER, 2012). Vale observar também que a efervescência que elas produzem pode ser conservadora - quando resultam na renovação da fé em ideais já existentes, criativa - quando gera novos princípios morais -, e destrutiva - quando sua consequência é basicamente a destruição dos princípios morais.
} 
Sociologias, Porto Alegre, ano 17, no 39, mai/ago 2015, p. 110-162

reprodução da vida moral e se tornam especialmente necessários e intensos em momentos em que o coletivo enfrenta alguma fragilidade.

Uma vez que estamos falando sobre a França e seus símbolos, podemos fazer referência aos eventos ocorridos naquele país em janeiro de 2015, isto é, o ataque à revista Charlie Hebdo e sua reação subsequente. O fato gerou uma demonstração pública massiva, com a multidão proclamando palavras que recordam os valores sagrados, na forma do veIho jargão Liberté, Égalité et Fraternité, ou do recentemente criado Je suis Charlie, uma forma de prestar solidariedade, não apenas às vítimas, mas também à "alma" do país - ao menos segundo algumas interpretações - e o funeral dos mortos, honrados como heróis. Ao mesmo tempo, também gerou uma reação ao último slogan, traduzida na expressão Je ne suis pas Charlie, para expressar a insatisfação com um certo tipo de secularismo, intolerante à diversidade cultural, considerado aquele apoiado pela revista. De um modo ou de outro, estamos falando sobre símbolos e rituais que fortalecem ou questionam velhos valores ou, pelo menos, a forma assumida por esses nas práticas contemporâneas.

Esse último exemplo também nos ajuda a evidenciar quão enganosas são certas interpretações (TAYLOR, 2003) que acusam Durkheim de considerar o sagrado como igualmente válido para toda a sociedade, como se tivesse a mesma extensão dessa. O problema com este tipo de interpretação é que a sociologia durkheimiana seria vista, segundo ela, como incompatível com o pluralismo religioso e, mais ainda, com a visão pós-secular. O que defendemos aqui é o oposto: a sociologia durkheimiana, especialmente em "Les Formes Élementaires", é perfeitamente compatível com a existência de pluralismo religioso e dos ideais pós-seculares, pois concebe uma cibernética do sagrado, que inclui o ritual, como sendo relativa aos vários grupos que coabitam o espaço social, sugerindo uma ideia policêntrica de sociedade, com múltiplos valores, formas de sagrado

http://dx.doi.org/10.1590/15174522-017003904 
Sociologias, Porto Alegre, ano 17, no 39, mai/ago 2015, p. 110-162

e fontes de rituais (ROSATI, 2009, p. 97, 2015, cap. 1). Essa forma de compreender a sociedade como uma rede complexa de grupos com seus próprios valores sagrados é vital para o programa de investigação que estamos propondo aqui e para compreender os desafios normativos na sociedade contemporânea.

\subsection{A Moral e a constituição do self}

O debate anterior sobre os vários aspectos que constituem o fenômeno da moral e o processo envolvido em sua criação nos dá uma ideia da moralidade como um fenômeno social. Agora queremos abordar como esta teoria inclui uma teoria subjacente sobre o indivíduo e a constituição do self, a qual pode se revelar bastante útil para expandir os horizontes daquela que poderia ser considerada uma sociologia da moral durkheimiana. A discussão da moral como dever e como bem carrega uma perspectiva importante sobre a natureza humana e os processos de constituição do self individual. Nas aulas de Durkheim sobre a educação moral (1925a), essa discussão é apresentada em termos de quais inclinações são requeridas de uma pessoa para que ela possa se tornar um "ser moral", ou seja, o que é preciso para que uma pessoa esteja apta a seguir regras morais, reconhecer princípios morais como algo desejável e, quando for o caso, ter uma atitude racional em relação a esses princípios.

Vamos começar com a dimensão do bem, na qual o equivalente individual é menos problemático. A disposição básica para um indivíduo ser capaz de sentir os valores morais como algo bom é o que o autor chama de o espírito de adesão ao grupo, que significa nossa habilidade de sentir prazer na vida coletiva, sugerindo certo grau de altruísmo, necessário para nos sentirmos conectados a algo além de nós mesmos. O que é interessante em sua explicação é a ideia de que nós não somos 
Sociologias, Porto Alegre, ano 17, no 39, mai/ago 2015, p. 110-162

estritamente egoístas, nem estritamente altruístas; então, esta segunda característica precisa ser acentuada através da educação. Implícita aqui está a ideia de que somos uma combinação de elementos naturais/individuais e sociais, já que mesmo algumas de nossas tendências mais básicas como egoísmo e altruísmo - podem ser desenvolvidas em uma ou outra direção, dependendo do curso de nosso processo de socialização (WEISS; PERES, 2014). Esse também é um elemento necessário para a vida moral, porque a conexão com um ideal social exige do indivíduo participar do processo coletivo que consagra ou renova a fé no ideal; a vida coletiva precisa ser uma fonte de prazer. Do ponto de vista do desenvolvimento do eu, isso é importante, porque nessa tradição um indivíduo só pode desenvolver plenamente seu potencial quando leva uma vida coletiva, quando tem interações sociais significativas que o ajudam a definir seus papéis sociais e desfrutar os sentimentos positivos produzidos pela efervescência coletiva.

No caso do dever, demanda-se do indivíduo, primeiro de tudo, a capacidade de ter uma conduta regular, de seguir regras e de aceitar autoridade externa, na medida em que uma ação moral não supõe seguir regras autoimpostas, mas, sim, regras estabelecidas por uma autoridade externa - Deus, os ancestrais ou até mesmo qualquer tipo de assembleia deliberativa. Isso significa que, para ser parte de uma comunidade moral, o indivíduo precisa aceitar limites, lidar com limitações para suas ações e suas paixões. A primeira consequência é que, fazer parte de uma comunidade moral é experimentar algum tipo de sofrimento, que poderíamos chamar de o páthos da limitação. Isso toca imediatamente nossos brios modernos e parece ferir nosso valor da liberdade individual. Nesse ponto, as coisas começam a complicar-se e se tornam interessantes. Ao invés de uma recusa imediata dessa ideia de moralidade como algo que implica heteronomia e restrições à liberdade, propomos ser precisamente este

http://dx.doi.org/10.1590/15174522-017003904 
aspecto tão controverso o que pode contribuir de modo significativo para compreender o que é necessário para possibilitar ao indivíduo evitar uma segunda - e mais profunda - privação, o páthos do infinito.

Conforme Durkheim - e nesse aspecto ele se aproxima muito da visão de Freud - o ser humano tem a tendência de sempre querer mais, assim como as paixões têm a tendência de se expandirem rumo ao infinito, o que pode ter consequências desastrosas não só para a vida social, como também para a individual, pois implicaria nunca alcançar os próprios objetivos, uma vez que o infinito é inatingível. Essa ideia de uma limitação necessária não é banal e sua história remonta a Aristóteles, Kant e Hegel, sendo compreendida como Grenze, como o limiar, que tem uma conotação positiva, já que é constitutiva da identidade moral e de um ego equilibrado (PICKERING; ROSATI, 2008, p. 73). Em resumo, se regras morais representam uma limitação dolorosa, elas também podem ser vistas como um ônus necessário, fazendo um papel similar ao da força da gravidade, que nos mantém com os dois pés no chão.

Essa limitação ocorre através de regras que não só determinam modos de agir na vida cotidiana como também em momentos excepcionais, como os rituais. Isto é, as regras sociais nos dizem quando nos reunir como grupo, por exemplo, em eventos comemorativos - aniversários, Natal, dias cívicos - e também como comportar-nos em momentos cruciais da vida como casamentos, funerais, etc. O problema com isso é que, algumas vezes, a prescrição não coincide com o que gostaríamos de fazer, embora, como veremos na última seção, um problema ainda maior seria ter que descobrir por nós mesmos o que fazer em cada ocasião corriqueira ou importante de nossas vidas. A feliz promessa de liberdade desapareceria rapidamente, frente à constante necessidade de tomar decisões - sejam pequenas ou grandes - como se o processo de construção da própria identidade tivesse que ocorrer repentinamente, sem diretrizes, como veremos mais ao final. 
Sociologias, Porto Alegre, ano 17, no 39, mai/ago 2015, p. 110-162

Agora, não seria esta dimensão incompatível com a moderna exigência da racionalidade, que exige desenvolver o "espírito da autonomia"? Bem, sim e não. Sim, se compreendermos a autonomia como a prerrogativa de agir apenas de acordo com as regras estabelecidas por um indivíduo, sem a influência de uma fonte externa. Mas isso não seria possível nem desejável. O que se sugere aqui é a ideia de aceitação esclarecida, que significa a possibilidade de conhecer o verdadeiro sentido de nossos valores - o que está em jogo quando alguém defende liberdade, igualdade e fraternidade - e a importância de seguir as regras necessárias para ser coerente com esses valores. Sob o ponto de vista do self, isso significa que podemos realizar uma ação informada, ou seja, agir sabendo por que estamos agindo, uma atitude que encoraja uma reflexão crítica. Tal reflexão, é claro, pode ter como consequência o questionamento das regras sociais estabelecidas, que pode ser o ponto de partida para alguma ação política, a qual tem a esfera pública como palco, o lugar onde diferentes visões de mundo disputam legitimidade.

Esse tipo de indivíduo autoconsciente corresponde ao ideal moderno de autonomia e pode ser compreendido como um tipo de self totalmente novo, criado com a promessa de libertar o indivíduo das correntes da tradição. Contudo, o que aprendemos com essa teoria é que a independência completa não é boa para um desenvolvimento saudável da própria individualidade que consagramos como nosso sagrado máximo. Implícita aqui está a ideia de que podemos ter consciência de todos os determinantes de nossa vida, mas não podemos simplesmente fazê-los desaparecer. Isso abre espaço para a crítica social e até mesmo para o radicalismo, mas é preciso aceitar que qualquer transformação radical requer sempre uma mobilização política e um compromisso com novas regras e valores os quais, para se tornarem morais, precisam ser compartilhados, criando uma nova rede de constrição social. A sociologia da 
Sociologias, Porto Alegre, ano 17, no 39, mai/ago 2015, p. 110-162

moral poderia se tornar um elemento importante desta atitude crítica, uma vez que pode ser vista com um tipo de psicanálise social (ALEXANDER, 2013; BELLAH, 1990), que desvela o papel do sagrado e dos rituais em nosso cotidiano. Analisada dessa forma, a sociologia da moral pode ajudar a desvendar processos e ideias que frequentemente seguimos, sem saber de onde vêm. Isso pode encorajar uma autocrítica, pois podem-se expor os processos sociais por trás de coisas que consideramos verdades óbvias. Por outro lado, nos torna conscientes da fragilidade dos valores tidos como sagrados, lembrando da possibilidade de rejeitá-los ou, caso continuem sendo aceitáveis e plausíveis após análise crítica, pode encorajarnos a lutar por eles, ritualizá-los e encontrar mecanismos para renovar nossa fé nos mesmos, assim como as mais diversas religiões nos ensinaram a fazer no decorrer dos séculos. Isso nos ajuda a desvelar os mitos, para que possamos criar outros, novos.

\section{Estabelecendo um programa de pesquisa: limites e temas da sociologia da moral durkheimiana}

No contexto da escola durkheimiana, a sociologia é uma disciplina científica geral, dividida em várias subáreas, que focam temas específicos e aplicam o mesmo método, aquele apresentado em "Les Régles de la Méthode Sociologique" (DURKHEIM, 1895a). Entretanto, consideramos ser mais produtivo seu debate teórico do que suas questões epistemológicas e metodológicas e sugerimos que esse aspecto deva ser renovado por um debate mais contemporâneo, tendo em vista esse marco teórico ser consistente com múltiplas estratégias metodológicas. Na presente seção, abordaremos temas e níveis de análises que podem ser investigados sociologicamente, uma vez que aceitemos trabalhar com essa compreensão básica da moral como um fenômeno social, conforme discutido acima. 
Sociologias, Porto Alegre, ano 17, no 39, mai/ago 2015, p. 110-162

Essa abordagem é considerada complementar a outros três campos de investigação, quais sejam, filosofia moral e política, psicologia e psicanálise e, finalmente, neurociências.

É relevante enfatizar isso, quando assumimos a moral como um fenômeno complexo, que permite uma abordagem por diferentes disciplinas (WEISS; PERES, 2014). Portanto, assumir a moralidade como um fato socialmente construído não exclui esforços filosóficos para fundamentar uma moral melhor, verdadeiramente justa, e tampouco discutir seus princípios, etc. Mas implica considerar esse esforço como parte do mundo social, um esforço consistente com nossa cosmologia ocidental moderna, que demanda princípios morais autorreflexivos e logicamente consistentes. Ao mesmo tempo, assumir a moralidade como um fato social não significa ignorar a participação individual em sua criação, nem considerar irrelevante o foco em como diferentes indivíduos assimilam - ou não - diferentes princípios morais, como reagem a esses ao formar suas próprias identidades, e até pavimentam o caminho para esforços conjuntos. Isso nos permite refletir, por exemplo, nas consequências - para a sociedade e para o indivíduo - de encorajar socialmente diferentes tipos de ego (WEISS; PERES, 2014). Finalmente, também a consideramos um campo complementar das ciências biológicas - uma perspectiva ainda controversa entre cientistas sociais e, poder-se-ia dizer, não sem razão - conquanto se admita existir dimensões fisiológicas que podem, efetivamente, interferir no comportamento moral, como é o caso de disfunções neurológicas que podem levar um indivíduo à total falta de compaixão ou comprometer sua faculdade de distinguir entre o bem e o mal, de acordo com os padrões sociais e assim por diante. 


\subsection{Unidade de análises: o espaço social como uma rede complexa}

Nosso programa de investigação estabelece que a vida moral de qualquer grupo social pode tornar-se objeto de investigação, contanto que o grupo seja estruturado em torno de alguns princípios morais, e não apenas utilitários e coercivos. A melhor maneira de fundamentar essa ideia é recorrer ao conceito de Shil, da dinâmica entre o centro e a periferia (SHILS, 1975, cap. 1) - reinterpretado para compreender mudanças estruturais em sociedades pluralistas - aplicado à sociologia durkheimiana com vistas a compreender fenômenos morais e religiosos (ROSATI, 2015). Isso nos permite "desembrulhar" e "desenredar" o conceito de sociedade de Durkheim, pois,

se alguém o fizer, o que verá é uma sociedade plural, internamente articulada em grupos intermediários, capazes de desenvolver sua própria consciência e moralidade coletivas, a partir de uma perspectiva ascendente, um ponto que Durkheim nunca abandonou, durante todo o seu desenvolvimento intelectual (ROSATI, 2009, p.139).

A ideia básica de Shils é de que toda sociedade tem seu centro - o núcleo de tudo o que é verdadeiramente sagrado, os símbolos, valores, crenças, etc. - e uma periferia, onde pessoas comuns e instituições levam suas vidas normalmente, tendo o centro como referência constante, por ser a fonte da identidade coletiva e das regras que os indivíduos devem seguir no dia-a-dia. Uma ideia interessante é de que este centro é a fonte da legitimidade e o guardião daquilo que o autor chama de Máximos Postulados Sagrados (MPS) (Ultimate Sacred Postulates - USP), que são os valores mais preciosos, os quais não podem ser confrontados sem provocar mudanças importantes nesses MPS. Assim, esse constitui um instrumento interessante para compreender as dinâmicas sociais. Normalmente, o centro pode manter sua autoridade, enquanto os MPS forem aceitos 
Sociologias, Porto Alegre, ano 17, no 39, mai/ago 2015, p. 110-162

como crenças compartilhadas, que podem ser consideradas tradições quando fazem parte de uma cadeia ininterrupta, conectando o presente e o passado. Essa última, quanto mais longa, será provavelmente mais enraizada e mais difícil de ser questionada, a não ser em circunstâncias de profundas mudanças estruturais na periferia. A contestação dos MPS é normalmente realizada através do questionamento do próprio centro, o que demanda o estabelecimento de uma nova fonte de autoridade.

O modelo de Shils é referido a uma ideia clássica de sociedade que tem um único centro, como seria o caso de uma sociedade baseada em uma solidariedade mecânica. Ao mesmo tempo, a sociedade contemporânea não exprime sequer o modelo clássico de solidariedade orgânica, no qual a solidariedade acontece como uma consequência da divisão do trabalho, necessitando apenas de um mínimo sagrado comum. O cenário contemporâneo, ao menos na maior parte das sociedades ocidentais, é o de sociedades sem centro, no sentido de que são territórios marcados por uma pluralidade de grupos com seus próprios centros. De fato, dentro de um espaço social, temos uma pluralidade de grupos de diferentes tipos. A distinção básica que podemos sugerir aqui é entre grupos secundários tradicionais e não-tradicionais. Na terminologia durkheimiana, um grupo secundário é toda forma de associação civil que é maior que a família e menor que o Estado. Podemos acrescentar a esta ideia a definição de tradição de Shil, compreendida como um grupo com duração - não efêmero - com um dado caráter, estilos de vida específicos que o definem em relação a outros grupos específicos ou sociedades como um todo, e com um centro estabelecido em torno de Máximos Postulados Sagrados. Os grupos secundários que não têm essas características podem ser considerados grupos secundários não tradicionais e, mesmo que o grupo tenha seus próprios ideiais e identidade, esses exigem menos de seus membros em termos de formação de suas identidades e dissolução de seus egos na comunidade.

http://dx.doi.org/10.1590/15174522-017003904 
Sociologias, Porto Alegre, ano 17, no 39, mai/ago 2015, p. 110-162

Como exemplo, podemos pensar no movimento feminista norte-americano na década de 1960. Esse era um grupo constituído há algum tempo, com integrantes compartilhando os mesmos Máximos Postulados Sagrados, que se organizava de certa forma e exigia de suas integrantes um alto nível de comprometimento - não apenas de engajamento em atividades políticas, mas também de atitude em relação aos homens, fossem eles marido ou colegas de trabalho, em relação ao modo de vestir, etc.. Esse grupo desafiava um grupo maior, que podemos chamar de Sociedade Americana, o qual tinha uma visão já estabelecida sobre as muIheres; e poderia haver um tensionamento ainda mais agudo em relação a tradições mais conservadoras que coabitavam o mesmo espaço. É interessante observar que, no contexto da sociedade global, essas tradições podem tornar-se internacionais, o que significa que uma feminista norte-americana talvez tenha mais em comum com uma feminista francesa do que com uma mulher católica sua vizinha de rua. Um grupo secundário não tradicional poderia ser, por exemplo, uma associação de ciclistas: eles podem se reunir para pedalar ou até mesmo para se envolverem em ações políticas em defesa de um tráfego mais inclusivo de ciclistas, mas provavelmente não terão muito mais em comum do que isso, não terão de fato um centro com Máximos Postulados Sagrados.

Para deixar as coisas ainda mais complexas, podemos acrescentar um possível tipo final de comunidade, que seria inconcebível duas décadas atrás: uma comunidade virtual, viabilizada pela internet e fomentada pelas redes sociais. Isso significa não apenas a existência de uma comunidade internacional, com pessoas pertencentes a diferentes territórios, mas também a união de pessoas que nunca se encontraram em um mesmo espaço físico. Relevante, aqui, é o fato de uma tal comunidade poder reunir indivíduos que, de outra forma, dificilmente se encontrariam, pelo simples fato de serem, frequentemente, minorias que não são aceitas 
Sociologias, Porto Alegre, ano 17, no 39, mai/ago 2015, p. 110-162

por nenhuma sociedade política ou mesmo por grupos tradicionais ditos "normais". Como um exemplo extremo, podemos refletir sobre grupos de pedófilos que, ao se encontrarem em redes sociais virtuais, podem desenvolver um senso de comunidade ao compartilhar as mesmas visões de mundo e ainda podem desenvolver seus próprios MPS.

Uma das missões da sociologia da moral que estamos propondo poderia ser aprofundar a compreensão sobre esta multiplicidade de grupos e tipos de grupos. Isso significa uma pesquisa empírica focada em quaisquer desses níveis, tratando de compreender seus aspectos formais e/ou substanciais, ou de tentar avaliar as implicações da interação entre diferentes grupos. Essa discussão também é importante para se pensar o que se pode considerar uma sociedade e se é possível falar em uma "sociedade global", que vise regular a vida em cada canto da terra, ou apenas a daqueles países que aceitam ser parte de uma comunidade internacional maior, como a ONU. E, o que dizer daqueles indivíduos que, tendo nascido em determinado país, não compartilham seus valores? Não se trata de dar respostas, mas, através da investigação das dinâmicas desses diferentes grupos em diferentes níveis, pode-se aportar novos elementos para o debate.

\subsection{Categorias de análise}

A análise formal é um dos níveis possíveis de uma investigação empírica que pode nos ajudar a perceber peculiaridades de diferentes grupos morais, em termos de suas características gerais. Isto é importante, na medida em que permite classificar estes grupos de acordo com diferentes categorias que, como veremos, podem ter diferentes consequências. Todas essas categorias são baseadas em premissas ontológicas apresentadas na primeira seção e consistem num esforço de aprofundar nossa visão sobre a complexidade do fenômeno moral. Em alguns casos, trazemos 
Sociologias, Porto Alegre, ano 17, no 39, mai/ago 2015, p. 110-162

distinções que são discutidas mais minuciosamente em outros trabalhos e, em outros casos, as categorias serão apenas brevemente indicadas, devendo ser mais desenvolvidas no futuro.

O primeiro elemento são os diferentes tipos de fontes de autoridade moral, relacionados ao tipo de fonte de moral que cada comunidade reconhece como legítima ou, em outras palavras, é o fundamento da validade: A base da rede simbólica pela qual nos relacionamos com a realidade e reproduzimos nossos modos de vida (FERRARA, 2002, p. 1). O que está em jogo aqui não é o efetivo processo de criação de um conjunto de ideais, mas o que o grupo aceita como verdadeiro e válido. Do ponto de vista formal, podem-se conceber seis tipos de fontes típico-ideais, quais sejam:

1) Divindade Direta, na qual se pode incluir todo tipo de situação em que o grupo acredita que os princípios morais foram diretamente comunicados a uma pessoa ou grupo. Este é o caso da moral Cristã, na qual o próprio Deus se tornou pessoa e revelou a verdade eterna;

2) Divindade Indireta, uma fonte que também é extramundana, mas é transmitida de forma mediada por profetas, sacerdotes e até mesmo por ancestrais que podem ter estado em contato com a deidade e transmitido a mensagem. Podem-se incluir aqui todas as religiões abraâmicas, em que Deus falou diretamente com Abraão, o qual transmitiu sua mensagem a seu povo que a repassou de geração em geração;

3) Tradição, uma fonte intramundana em que a justificativa de agir de certa maneira é por esta ser a forma como as coisas sempre foram feitas, ou porque a autoridade da sabedoria infinita dos ancestrais assim o determina, como no caso da Grécia clássica - é o tipo de moralidade que Sócrates e seus discípulos começaram a questionar. Mesmo sendo uma fonte intramundana, também é totalmente heterônoma, uma vez que o indivíduo não tem qualquer influência em relação a ela e o que se espera dele é, meramente, reproduzir um comportamento cristalizado; 
Sociologias, Porto Alegre, ano 17, no 39, mai/ago 2015, p. 110-162

4) Esfera Pública, compreendida como um grupo de pessoas autônomas pensando e agindo juntas, através de um processo deliberativo, como no modelo ideal habermasiano. Essa é também uma fonte intramundana e o indivíduo tem algum grau de autonomia, na medida em que participa do processo; mas também existe uma certa dose de heteronomia, uma vez que os ideais e regras morais resultantes desse processo não são inteiramente sua criação e, provavelmente, não coincidirão plenamente com suas ideias.

5) Razão Transcendental, fonte consagrada pela história da filosofia moral, consiste no ideal de autonomia kantiano, em que a razão é compreendida como uma faculdade que, mesmo se compartilhada por outros e existindo objetivamente, também é parte da própria pessoa. Portanto, não é uma fonte transcendente, mas sim transcendental, na qual uma parte específica do indivíduo - a razão - tem um papel ativo na determinação do que é a coisa certa a fazer em cada situação. Aqui, o racional é compreendido como um equivalente da verdade e do certo.

6) Ego Autêntico, na qual o indivíduo, como um ego constituído por razão e sensibilidade, é considerado a única autoridade legítima para decidir sobre o que é o bem e como deve agir, criando seus próprios ideais e regras. Esta é uma fonte totalmente intramundana, sem qualquer tipo de mediação envolvida e pode ser relacionada com as éticas da autenticidade (FERRARA, 2002).

Uma segunda característica formal importante é o equilíbrio entre a coletividade e o individual, que se estende do coletivismo extremo ao atomismo extremo, significando que, independentemente do que seja estabelecido como regras e valores específicos, diferentes sistemas morais podem conceber diferentes níveis de liberdade para ação individual. Podemos identificar três confiigurações características: 
Sociologias, Porto Alegre, ano 17, no 39, mai/ago 2015, p. 110-162

1) Coletivismo pleno - situação em que os objetivos coletivos sobrepõem qualquer preferência individual, exigindo, inclusive, atos de autossacrifício em nome de um bem comum. Isso pode acontecer no contexto de uma heteronomia total ou moderada. A primeira não pode ser considerada integralmente moral, pois se trata de uma situação em que o indivíduo não reconhece o princípio estabelecido como sendo bom e legítimo, e seu consentimento é baseado no medo. Este é o caso das ditaduras totalitárias, e não pode ser considerado um sistema moral, mas, sim, um estado patológico. Um coletivismo pleno com heteronomia moderada é uma situação em que o indivíduo não tem voz ativa no estabelecimento de regras, mas aceita sua legitimidade e concorda com seus princípios. Poderíamos pensar, por exemplo, em uma situação de guerra, quando se pede às pessoas que devotem sua vida ao seu país.

2) Sociedade civil equilibrada - refere-se ao conceito de sociedade civil para descrever uma situação ideal em que as pessoas têm o direito de preservar suas individualidades, que se constituem no processo de participação em diferentes grupos existentes em uma esfera mais ampla que sua família e menor que o estado, desde que a participação não seja totalitária. Isso corresponderia, aproximadamente, à situação descrita por Durkheim em Leçons de Sociologie como o ideal democrático. Os níveis de heteronomia também podem variar amplamente, desde nenhuma participação na criação das regras, ou mesmo a recusa de sua validade, até uma situação de total autonomia, compreendida como a possibilidade de participação no processo de criação dos princípios morais. Mas o importante é como esses princípios - autônomos ou heterônomos interferem na vida individual. Esta seria uma situação em que a pessoa é demandada a sacrificar aspectos de sua vida pessoal em prol do bem comum, mas teria espaço suficiente para crescer individualmente. 
Sociologias, Porto Alegre, ano 17, no 39, mai/ago 2015, p. 110-162

3) Individualismo Pleno - o outro extremo da configuração descreve um contexto em que cada indivíduo é encorajado a buscar seus próprios interesses e esta ação é moralmente sancionada. Este é um contexto típico de certo tipo de utilitarismo, ou de todo princípio moral que não requer levar em consideração o "bem comum". Sob a perspectiva trabalhada aqui, esse também pode ser considerado um estado patológico, já que - a menos que de fato exista uma mão invisível fazendo com que tudo concorra para o melhor - o efeito mais provável seria a falta de solidariedade social, que afetaria os próprios indivíduos os quais este ideal deveria encorajar, especialmente aqueles em posição menos favorável no grupo.

Uma terceira categoria é a extensão da validade da moral grupal, a qual pode almejar aplicar-se apenas aos membros do grupo ou reivindicar uma validade universal, e demanda diferentes tipos de relações com o sagrado. Isso implica maior ou menor proselitismo e envolve um dos temas mais complicados no debate da filosofia moral e política, especificamente, a do relativismo versus universalismo, suscitando a questão de em que medida os Máximos Postulados Sagrados do ocidente podem aplicar-se a todas as culturas. Algumas das configurações possíveis de extensão da validade são as seguintes:

1) Intragrupo - os princípios morais estabelecidos como sagrados por um grupo são considerados válidos apenas para os membros do grupo, com uma nítida distinção entre "nós" e "eles". Não há a intenção de mudar o mundo exterior, e dificilmente haverá situações de tensão com o grupo maior, a menos que as normas do grupo demandem dos membros entrar em conflito com as leis do grupo maior. Um exemplo seria o caso de alguns grupos religiosos que não permitem a seus membros receber transfusão de sangue.

2) Além-do-grupo - refere-se a um grupo estruturado ao redor de um centro, mas cujos Máximos Postulados Sagrados pretendem ser váli- 
Sociologias, Porto Alegre, ano 17, no 39, mai/ago 2015, p. 110-162

dos para todo mundo, ou pelo menos no contexto da sociedade mais ampla. Assim, observa-se uma atitude ativa, ou mesmo ação política, visando à conversão. Esses MPS podem tanto ser restritivos, no sentido de que impõem suas próprias regras de forma a serem mais restritivas do que aquelas válidas para todo o grupo, como podem ser menos restritivas, quando estabelecem um princípio que sugere uma moralidade mais flexível.

3) Intergrupos: ocorre quando questões morais são transformadas em legislação com validade aplicada à sociedade como um todo. Podem existir três classes distintas de valores sagrados intergrupos: A) os consensuais, ou consensuais para a maior parte da população, subdivididos entre - A1) aqueles que asseguram a coexistência entre diferentes grupos [como liberdade de crença]; A2) aqueles considerados como um bem pela maioria do grupo [proibição de assassinato]. B) os não-consensuais: aqueles que se aplicam à sociedade como um todo, mas cuja validade divide a sociedade, como por exemplo: aborto, casamento gay, legalização de drogas, etc.

Uma quarta dimensão analítica refere-se aos diferentes tipos de atitude entre indivíduos promovidas por sistemas morais específicos, no que diz respeito ao que se espera do comportamento das pessoas em relação a outras - que pode ser de empatia, simpatia, apatia ou antipatia. Aqui está implícita a ideia de que cada ego se desenvolve como resultado de um conjunto complexo de elementos, mas as expectativas sociais têm um papel importante, reprimindo ou encorajando diferentes tipos de comportamento. Quatro categorias, mais extensamente trabalhadas e outros textos (WEISS; PERES, 2014, p. 87-91), podem ser resumidas conforme segue:

1) Ego-empático - o que sente as alegrias e dores dos outros como se fossem suas e é capaz de fazer grandes sacrifícios pelo bem dos outros, inclusive aniquilando sua própria personalidade e bem estar. 
Sociologias, Porto Alegre, ano 17, no 39, mai/ago 2015, p. 110-162

2) Ego-simpático ou solidário: aquele capaz de reconhecer e compreender o que ocorre com outros indivíduos e, de alguma forma, comove-se com isso, mas não sente como se fossem suas próprias alegrias ou necessidades, o que implica um limite para a ajuda que prestaria a outros que estejam necessitados.

3)_Ego-apático ou indiferente - o que não é sensível às alegrias e dores dos outros. Para esses indivíduos, o que acontece com os outros como consequência de suas ações é irrelevante, e suas relações com outros, quando ocorrem, sempre visam um objetivo pessoal, o outro sendo meramente um meio necessário para atingir seu objetivo.

4) Ego-antipático ou hostil - aquele movido pelo sentimento de antipatia, experimentado como hostilidade, ódio, etc.. Sua ação é baseada nesse sentimento negativo, que tem como propósito causar algum tipo de desconforto no outro, desde um constrangimento leve até as atitudes mais agressivas, como no caso de tortura e assassinato.

A quinta dimensão refere-se aos tipos de ação moral, que envolvem o debate sobre o papel que elas desempenham em diferentes contextos sociais e seu potencial para induzir transformação da moralidade. Sugerimos que uma sociologia durkheimiana poderia ampliar-se pela inclusão das ações morais como um aspecto analítico relevante, que pode ser categorizado como:

1) Totalmente moral - uma ação conforme às regras, consideradas adequadas pelo indivíduo. Nessa situação, a ação do indivíduo está de acordo com o que é moralmente aceito e também é considerada como um princípio moral subjetivo, de forma que existe conformidade entre princípios subjetivos e intersubjetivos. Na obra de Durkheim, esta distinção analítica não está explícita, mas é, de alguma forma, pressuposta.

2) Em conformidade com as regras socialmente sancionadas quando a ação é considerada legítima pelo grupo, mas não coincide com 
Sociologias, Porto Alegre, ano 17, no 39, mai/ago 2015, p. 110-162

o que o indivíduo considera a coisa certa a fazer. Nesse sentido, suas ações concordes com o princípio moral intersubjetivo podem seguir dois tipos diferentes de motivação, quais sejam: 2.1) sua convicção de que existem outras coisas boas no grupo e de que um comportamento diferente do esperado pode causar tensão social e ele quer evitar isso; ou, 2.2) puramente, medo das sanções.

3) Ação imoral, quando o indivíduo se comporta de maneira contrária ao que os princípios morais estabelecem para o grupo, para a qual se podem visualizar três diferentes situações. 3.1) fraqueza de caráter, quando o indivíduo concorda com os princípios morais, mas falha em seguí-los, sendo levado por fortes ímpetos a ter um comportamento imoral, contra sua própria consciência, tendo como resultado não apenas uma sanção interssubjetiva, mas também uma subjetiva: a culpa. Um caso interessante para refletir sobre esse tipo de ação imoral é o de uma relação extraconjugal em que a pessoa experimenta culpa e vergonha, e qualquer sanção social será considerada bem merecida, ajudando no processo de expiação da culpa. 3.2) imoralidade oculta, quando o indivíduo leva uma vida dupla, conduzindo ações imorais secretamente, mesmo ao considerar correta a forma como se comporta. Esta situação se poderia considerar uma "hipocrisia consciente", no sentido de que a pessoa acredita que tornar público seu comportamento causaria dor à família ou mesmo consequências perturbadoras para o grupo como um todo. Assim, para o indivíduo, suas ações são morais, mas seriam imorais para o grupo e, ao mantê-las secretas, evita as consequências. Pode-se tomar como exemploo caso da famosa escritora Anaïs Nin, quem, no primeiro estágio de sua vida conjugal, teve vários parceiros sexuais, ocultando o fato de seu marido e da sociedade, mas sem nenhum senso de culpa. Este exemplo é útil aqui, pois podemos relacionar o segundo estágio de sua vida com outro tipo de ação imoral, enunciado a seguir. 
Sociologias, Porto Alegre, ano 17, no 39, mai/ago 2015, p. 110-162

4) Desvio consciente e público dos princípios morais, que ocorre quando o indivíduo sabe que não segue as regras do grupo e aceita enfrentar suas consequências. Essa situação ocorre quando Anaïs tem outro marido, o qual descobre suas intensas atividades sexuais com outros homens e mulheres e a encoraja a publicar seus diários, em que sua vida sexual e sentimental é apresentada de forma muito detalhada. Uma ação como essa pode ter um papel muito significativo na vida moral de uma comunidade, ao exercer pressão por maior liberalização e mudando a maneira de lidar com comportamentos incomuns. De certa forma, o fato de Anaïs ter tornado público seu próprio comportamento desviante ajudou a abrir caminho para reivindicações contemporâneas de novas formas possíveis de relações eróticas, desde relacionamentos abertos, poligamia e até mesmo poliamor, as quais já têm suas próprias comunidades de luta para que se tornem um estilo de vida juridicamente aceito.

De maneira geral, este debate sobre a ação moral é particularmente relevante para nosso propósito, uma vez que nos ajuda a compreender novos aspectos subentendidos nessa perspectiva sociológica. Conforme mencionamos no início, de uma perspectiva durkheimiana, não faz sentido falar sobre uma "moral individual", da mesma forma que é impossível ter uma religião individual. Uma coisa é ter uma crença individual e, outra, uma religião ou moral individuais. Qual a razão disso? Porque, por definição, a moral é uma criação coletiva e, nesta, o ritual tem um papel chave como processo coletivo. O ideal, considerado o coração e a alma de cada sistema moral, precisa ser algo compartilhado, na medida em que apenas se torna um ideal moral depois de passar pelo processo coletivo de consagração.

Nesse sentido, um ideal moral nunca é uma crença individual, é sempre uma representação coletiva, internalizada pelo indivíduo e dotada de um status sagrado, sendo que o desafio a esta crença ou conjunto

http://dx.doi.org/10.1590/15174522-017003904 
Sociologias, Porto Alegre, ano 17, no 39, mai/ago 2015, p. 110-162

de crenças sempre implica em sanções pelo grupo. A adesão a esse ideal pode ser sincera, mas isso não é necessário ou suficiente. Não importa o quanto um único indivíduo elogia uma regra ou ideal específico; seu status de "ideal moral" ou "regra moral" depende do reconhecimento pelo grupo como tal. Este é o nível analítico que interessa a Durkheim. Obviamente, isso não significa que um indivíduo não possa ter seus próprios princípios de conduta, suas próprias ideias sobre como deveria ou não agir, sobre o que é importante e o que não é e, até mesmo, sobre algumas coisas que considera sagradas. Isso, contudo, é irrelevante sob o ponto de vista sociológico, pelo menos no paradigma em que estamos trabalhando. Exceto, é claro, em situações em que esse conjunto de crenças e regras pessoais levam a um certo tipo de comportamento que vai contra a moralidade do grupo.

Vejamos um exemplo muito simples, para esclarecer este ponto. Consideremos um homem que estabelece como sua máxima ajudar todos os cães que puder. Ajudar os cães é decisão sua, baseada em convicções ou sentimentos de que isso é significativo. Se este for um valor individual, não partilhado por outros, de modo a formar um grupo, não terá relevância sociológica. Mas, se este homem decidir que, para dispor de suprimentos suficientes para alimentar os cães, ele precisa roubar um supermercado, seus valores se tornam um problema. Ele passa a ser considerado um indivíduo desviante, que desacata a moral do grupo, a qual condena o roubo. Vale observar que este comportamento que poderíamos rotular como "anormalidade moral", pode trazer duas consequências diferentes, o que ajuda a compreender como podemos conceber a continuidade da moral e a transformação da moral. Uma primeira e mais provável consequência seria punir o ato, prendendo o sujeito salvador de cães e, assim, o grupo reforçaria o ideal moral de que não roubar é mais importante do que alimentar cães famintos. Mas, talvez, um grupo de in- 
Sociologias, Porto Alegre, ano 17, no 39, mai/ago 2015, p. 110-162

divíduos possa simpatizar com o desvio do homem e argumentar em sua defesa, ou mesmo começar a reproduzir seu comportamento.

Dependendo de sua evolução, esses fatos poderiam levar à criação de um novo sistema moral no grupo, não necessariamente justificando roubo a supermercados, mas afirmando que proteger e alimentar os cães é uma obrigação moral da sociedade como um todo. A esta altura podemos falar sobre novos ideais e regras morais, que podem tornar-se sagrados apenas para um pequeno grupo, ou mesmo para a maior parte da sociedade ou para a sociedade como um todo. Por mais absurdo que este caso possa parecer, as dinâmicas que tornaram o respeito pela natureza e pelos animais uma questão moral não diferem muito disso. Há algumas décadas atrás, usar um casaco de pele de raposa era sinônimo de luxo e bom gosto. Quem ousasse criticar uma pessoa por vestir uma tal peça seria, no mínimo, considerado inconveniente e, poderia mesmo ser banido de certos grupos sociais. Hoje, a situação é muito diferente: usar pele de animais não é considerado apenas fora de moda, mas imoral - quem ousar fazê-lo se sujeita à desaprovação moral e, talvez, no futuro, possa ser alvo até de sanção penal.

Esse parêntesis tem duplo propósito. Primeiro, desfazer a ideia disseminada de que a sociologia durkheimiana não contempla a mudança, ou considera ações individuais completamente impotentes. Porém - e este é um "porém" importante -, esta possibilidade não significa que qualquer desvio possa promover mudanças ou que um único indivíduo possa formar um mundo completamente novo. As condições para a mudança são bastante complexas e não há garantias, isso envolve uma boa dose de imponderável. O segundo propósito é destacar o desvio como um fenômeno central em cada sistema moral e, por essa razão, apontá-lo como um tema crucial para a sociologia da moral. Compreender as dinâmicas do desvio em relação ao sagrado talvez seja um dos elementos mais 
Sociologias, Porto Alegre, ano 17, no 39, mai/ago 2015, p. 110-162

importantes para compreender as tensões e transformações morais em um grupo ou em um conjunto de grupos que coexistem em uma mesma sociedade. Podemos concluir essa digressão, afirmando que um indivíduo desviante, em certos casos, pode ser considerado como um modelo (FERRARA, 2008), aquele cuja vida é considerada singular, autêntica, que não pode adaptar-se totalmente a qualquer fórmula moral já existente. Nesse caso, uma biografia individual pode ser tomada como uma "biografia exemplar", com princípios morais originais, uma vez que representa uma moral que não coincide com o "é" mas que "deveria ser" ou poderia ser, e este constitui outro tema possível para a sociologia da moral.

Essas características formais são apenas alguns dos aspectos constitutivos relevantes dos sistemas morais e, certamente, poderíamos incluir muitos outros, como os diferentes graus de normatividade, que vão desde conjuntos de várias e detalhadas regras até outros com poucas e elementares; a intensidade e força do centro; a tolerância em relação a outros sistemas morais; o grau de coesão social que ele exige ou promove; a tolerância em relação a diferentes tipos de sistemas morais; a intensidade e tipos de sanções, como no comparativo clássico que Durkheim apresentou em "De la Division du Travail Sociale", entre legislação punitiva e restitutiva; a coerência entre regras, ideais e ritos; a relação entre a moral do grupo e o sistema jurídico a que está submetido, e assim por diante. Isso é importante, pois permite ver que a moral pode assumir diferentes formas e, apesar de seu conteúdo específico, pode promover diferentes níveis de solidariedade social, de liberdade, ser mais ou menos beligerante, mais ou menos tolerante, etc.

Contudo, o conteúdo da moral também é crucial, porque, no fim das contas, é o que dirá aos indivíduos sujeitos à mesma o que podem ou não fazer. A investigação substantiva pode tratar das mesmas dimensões analíticas apresentadas aqui, mas visa descrever os conteúdos dos siste- 
Sociologias, Porto Alegre, ano 17, no 39, mai/ago 2015, p. 110-162

mas morais. Por exemplo, pode compreender a) quais são as regras específicas: o que as pessoas podem ou não fazer e as situações a que se aplicam; b) quais são os ideiais: o que as pessoas alegam ser o bem, o que é o mundo ideal, a sociedade ideal, o que é o bem acima de todas as coisas; c) qual é a suposta fonte - qual deus ou deuses? Quais ancestrais? Quais grupos deliberativos? Que tipo de "razão"?; d) quais são os ritos envolvidos na renovação do sistema moral; e) quais são os símbolos?; f) quais são as posições hierárquicas e papéis disponíveis?; g) que tipo de comportamento é considerado desviante? Todas essas questões podem funcionar como guias na investigação de diferentes grupos e podem aumentar nossa sensibilidade para múltiplas dimensões que estão subentendidas na vida moral, e isso tem consequências relevantes quando lembramos que o domínio da moral pertence ao domínio do sagrado. Na próxima seção, veremos as consequências desta discussão para uma avaliação crítica do mundo contemporâneo.

\section{A sociologia da moral como uma análise crítica: dilemas contemporâneos}

Um elemento polêmico e interessante no projeto durkheimiano da sociologia da moral é sua afirmação de que a sociologia não valeria um segundo de nossos esforços, se não pudesse nos ajudar a lidar com as dimensões práticas de nossa vida, a lidar com questionamentos morais e a encontrar melhores soluções para nosso futuro (DURKHEIM, 1893b, p. xxxviii). Apesar de atraente, esta afirmação não deve ser entendida pela ótica de um positivismo comteano, pois o que está implícito nela não é que a ciência pode nos dizer precisamente o que fazer, porque é capaz de descobrir o que é o bem, deduzindo o "deve ser" do "é", como no caso de uma falácia naturalista (JONES, 1995; JONES, 2001; MILLER, 
1996). Entender o significado dessa visão não é tarefa simples, pois requer ir além das leituras canônicas e considerar sua tese latina sobre Montesquieu (DURKHEIM, 1892) com sua discussão dos dois caminhos para o normal (MILLER, 1993; WEISS, 2011, cap. 3).

Colocado de maneira breve, a ideia é que conhecer a moralidade de um grupo e a relação entre grupos ajuda a ver mais claramente tudo o que está em jogo a cada momento: as consequências das diferentes formas, dos diferentes conteúdos, os paradoxos e aporias. Decidir o que fazer ainda depende de nós, seres humanos pertencentes a diferentes grupos e habitando o mesmo planeta. Não existem certezas, promessas de um caminho seguro, apenas possibilidades abertas, esforço e esperança. Nesta seção final, nosso objetivo é levantar alguns dos dilemas mais desafiadores do mundo contemporâneo, que devem ser de extremo interesse para qualquer investigação sobre a moral ou discussão política e filosófica e - por que não? - ser parte do debate público ao nos tornar mais conscientes deles.

O projeto de modernidade ocidental foi concebido como tendo, em seu núcleo, o propósito de permear cada atitude da vida humana com racionalidade. No que se refere à vida moral, isso tem um profundo impacto em duas dimensões específicas - são elas: a necessidade de substituir dogmas religiosos por fundamentos racionais, estabelecendo o conhecimento científico como a verdade suprema, e a consagração do indivíduo autônomo como o self típico ideal. Lentamente, esse excesso de confiança na validade da racionalidade atenuou-se, dando lugar a argumentos que justificam o fenômeno empírico hoje denominado "multiculturalismo". Este consiste não apenas no fato de diferentes culturas habitarem o mesmo espaço, mas também na crença de que essas culturas têm o direito de viver de acordo com suas próprias crenças, as quais não necessariamente coincidem com as crenças liberais, sem falar no fato de 
Sociologias, Porto Alegre, ano 17, no 39, mai/ago 2015, p. 110-162

ter inventado e consagrado um novo tipo de self, o self "autêntico" (FERRARA, 2002).

Obviamente, esse novo cenário traz um conjunto de potenciais patologias e desafios complexos. Uma questão que devemos colocar é se este tipo de tradição formal e racionalista pode ou não ter a mesma força normativa das tradições religiosas. É importante refletir sobre a possibilidade de crenças religiosas serem traduzidas em termos de crenças racionais, sem perder sua força de coesão e motivação, sem perder sua vitalidade. Em outras palavras, a força normativa de um sagrado transcendente pode ser transformada, sem perdas significativas, em um tipo de semi-sagrado? Afinal, as crenças religiosas têm um núcleo blindado de postulados sagrados que não podem ser questionados nem discutidos, protegidos como são por uma forte interdição, que os colocas acima de qualquer consideração linguística.

\subsection{Múltiplas fontes do self e o "dilema de Kundera"}

Sob o ponto de vista do desenvolvimento de personalidades individuais, esta tentativa de substituir a tradição religiosa por uma fé racional também tem grandes implicações. Para começar, podemos perguntar o que acontece com a adesão a um ideal comum em um contexto de estímulo a "egos" autênticos, que requer sinceridade de adesão a qualquer crença e não apenas rituais de afirmação do pertencimento. A crença subjacente ao ego moderno é de que a autoridade emana da franca aceitação de uma regra. Conforme a argumentação de Ferrara, autonomia e autenticidade constituem a base do projeto da modernidade ocidental e a tese da autenticidade afirma que a noção de subjetividade autêntica está para a modernidade contemporânea assim como a noção de subjetividade autônoma para o início da modernidade (FERRARA, 2002, p. 4). Contudo, num contexto de modernidades múltiplas, existem outros 
Sociologias, Porto Alegre, ano 17, no 39, mai/ago 2015, p. 110-162

fundamentos competindo, demandando validade, e nosso propósito aqui é trazer as implicações das discussões apresentadas na primeira seção, sobre o caráter complexo da natureza humana e os paradoxos associados ao peso excessivo e leveza excessiva. Isso contribui para desenvolvermos uma atitude crítica em relação aos diferentes sistemas morais, no que diz respeito às fontes do self, ao papel da tradição e aos questionamentos da autonomia.

Comecemos considerando uma escala imaginária onde, em um dos dois extremos, temos uma situação de plena heteronomia e, no outro, uma completa falta de regulamentação, conforme mencionado na segunda seção. No primeiro caso, a ação humana é totalmente controlada pelas regras sociais e nenhum desvio ocorre sem punição. Isso pode ser uma fonte de sofrimento profundo para o indivíduo, já que suas particularidades não podem ser toleradas, não há espaço para sua vontade e ele pode sentir-se sufocado pela predeterminação excessiva de cada passo seu. Mesmo quando o indivíduo concorda ou aceita a legitimidade da autoridade que impóe as leis, a vida pode se tornar muito pesada, muito sufocante ou pode provocar uma completa dissolução do self, como no caso descrito por Durkheim em sua análise do tipo de suicídio altruísta.

No outro extremo, temos uma situação de completa falta de regulamentação social. À primeira vista, parece a situação ideal em um mundo de pessoas completamente autônomas. Bem, para começar, da perspectiva durkheimiana, a simples ideia de que devemos ser totalmente autônomos já configura uma regra social ou, pelo menos, um ideal social. Sem falar que a própria ideia de autonomia implica certo tipo de regulamentação, mesmo se estivermos falando de uma regulamentação auto-imposta, determinada por imperativos racionais. Mas, para manter a situação típico-ideal da completa falta de regulamentação, podemos dizer que neste extremo da escala, não há qualquer senso de sociedade, não 
Sociologias, Porto Alegre, ano 17, no 39, mai/ago 2015, p. 110-162

há regras que nos digam o que fazer, nenhuma prescrição sobre o que se pode comer, com quem casar, quando nos reunir para celebrar ou o que fazer quando alguém morre. Nenhuma regra, ritual, laços, ou limites e, assim, nenhum senso de pertencimento. O ponto crucial aqui é a subestimação da profunda conexão entre a regulamentação e a vida coletiva - o coletivo aqui é compreendido como qualquer tipo de comunidade, tendo no mínimo duas pessoas em uma interação relativamente estável. Sob a perspectiva durkheimiana, isso traz um segundo tipo de patologia, cujas consequências são similares às do excesso de regulamentação: suicídio, do tipo anômico. Nessas formas extremas, a falta de regulamentação pode ser experimentada como uma liberdade total, como se fosse possível para o indivíduo voar para qualquer lugar. Mas este sentimento pode se tornar muito doloroso, o indivíduo pode perder o seu senso de direção, ao ponto de a leveza se tornar insustentável.

Ao mesmo tempo, podemos conceber a própria criação da autenticidade como um ego ideal, como resultado de excessivas pressões sociais, que provocam sofrimento insuportável aos indivíduos que não se adequam a elas. Como está claro nas discussões sobre reconhecimento (HONNETH, 1992; 2007), o sofrimento é um elemento importante nas dinâmicas sociais e pode se converter em lutas por reconhecimento que, de certa forma, podem ser compreendidas como esforços para ampliar a gama de identidades moralmente aceitas. Por exemplo, uma sociedade em que as disparidades de gênero trazem demasiado sofrimento às muIheres, ou que repudia relacionamentos homossexuais, produziria grande padecimento para os indivíduos, já que parte considerável da população estaria submetida a condições que não favorecem suas identidades.

Nesse caso, podemos falar de uma patologia hiperbárica, pois a manutenção da ordem social e dos Máximos Postulados Sagrados depende de um alto grau de repressão, o qual acaba por produzir desvios poten-

http://dx.doi.org/10.1590/15174522-017003904 
Sociologias, Porto Alegre, ano 17, no 39, mai/ago 2015, p. 110-162

cialmente críticos, devido à existência de indivíduos que não se encaixam aos papéis estritos, em um sistema que não admite pluralidade de papéis e de identidades. No outro extremo, podemos ter uma patologia hipobárica, como consequência de uma configuração moral em que o indivíduo não está conectado a nada além de si mesmo, quando muito. Quando dissemos que a modernidade consagrou o self - seja o autônomo ou o autêntico - como a fonte definitiva da ação moral, estamos falando da destituição de uma fonte externa, Deus ou os ancestrais - símbolos imanentes e transcendentes -, transformando o sujeito em seu próprio juiz. No que tange ao início da modernidade e seu ideal de autonomia, o que continua a existir é a oposição entre razão e impulsos, razão e emoção, uma cisão que reconhece apenas à primeira o direito à "autoridade moral" e à "validade moral", enquanto o segundo elemento da oposição permanece o mesmo da cosmologia abraâmica: um mal a ser combatido.

Por sua vez, o self autêntico, de acordo com Ferrara (2005), é uma criação da modernidade tardia e, mesmo que ainda pressuponha a ideia de autonomia como uma autodeterminação, introduz na equação a necessidade de conciliação com a dimensão volitiva do eu. Não no sentido desta se tornar o novo polo destinado a prover fundamento para a ação moral; ao contrário, é compreendida como um aspecto necessário da individualidade e deve ser levada em consideração ao se estabelecerem os princípios para guiar as ações humanas. Entretanto, a realização de um ideal de ego autêntico está longe de ser algo simples e requer diferentes tipos de considerações, inclusive psicanalíticas, uma vez que o ego autêntico também precisa ser equilibrado. A patologia hiperbárica poderia ser traduzida como o estabelecimento de um ego ideal demasiadamente abstrato, cujas dimensões identitárias são abertas demais, flexíveis demais, e não aportam ao indivíduo as condições necessárias para florescer de forma saudável, desenvolver um self verdadeiramente autêntico, pois não 
Sociologias, Porto Alegre, ano 17, no 39, mai/ago 2015, p. 110-162

existe um pano de fundo sobre o qual o indivíduo possa construir princípios para guiar sua própria vida. Afinal, esse processo não pode ocorrer em um vácuo. Essa situação ocorre quando o indivíduo não pertence a nenhum tipo de grupo secundário, quando existe um déficit afetivo em seu processo de socialização primária, que afeta tanto sua capacidade de seguir regras - sejam elas quais forem, mesmo aquelas auto-estabelecidas - como sua habilidade de estabelecer vínculos significativos com outras pessoas, com um grupo, ambas essenciais para o processo de reconhecimento e construção de um self saudável.

Por isso, ousamos dizer que, nesse sentido, o self autêntico ideal tem algo a aprender com aquelas configurações heterônomas que a modernidade tão intensamente combateu. Uma das características importantes das fontes tradicionais do self é o papel desempenhado pelos rituais. Conforme escreveu Durkheim em "Les Formes", os rituais são dotados de uma propriedade quase mágica de produzir um influxo energético extraordinário, dando sentido a ações comuns e consagrando momentos que são cruciais na vida do indivíduo, tais como aniversários, entrada na vida adulta, casamento, morte, etc. Se, por um lado, causam sofrimento ao impor práticas excessivamente uniformes, também podem proporcionar conforto, sentimento que, em muitos aspectos, é similar ao bem-estar provocado por substâncias psicoativas, analgésicos ou até mesmo como ser anestesiado. Afinal, diferentes tipos de ritos têm diferentes funções e diferentes efeitos. Nos rituais fúnebres, por exemplo, podemos encontrar uma dupla função: uma social e uma individual.

Por um lado, tais ritos informam à comunidade que, apesar do sofrimento causado por uma situação de tragédia, crise, doença ou morte, a vida coletiva permanece intacta - o "como se" consistindo em uma das propriedades fundamentais do rito (ver ROSATI, 2009) - e espera-se do indivíduo que se subordine ao propósito mais geral da vida coletiva. Por

http://dx.doi.org/10.1590/15174522-017003904 
Sociologias, Porto Alegre, ano 17, no 39, mai/ago 2015, p. 110-162

outro lado, também têm a função - diretamente associada à primeira de regular o período de luto, que dependerá da natureza da relação do indivíduo com a pessoa falecida. Esta ideia está fortemente relacionada à discussão de Freud em "Luto e Melancolia", na medida em que consideramos os rituais fúnebres como instrumentos sociais que ajudam o indivíduo a evitar uma situação de melancolia. O ritual e as convençõe sociais estabelecem, por exemplo, por quanto tempo uma pessoa viúva deve vestir-se de certo modo e eximir-se da vida social; após este período, espera-se que retome suas atividades normais e, em algumas culturas, que se case novamente o mais breve possível. Esta situação envolve tanto uma forte pressão social quanto uma carga emocional que determinam: "por tantos dias ou meses, você deve abster-se disto e daquilo e deve se comportar desta forma; depois disso, você deve deixar isso para trás e retomar sua vida normal".

Sim, configurações tradicionais impõem ao indivíduo alguns ideais pré-fabricados, mas, em contrapartida, fornecem a estabilidade de uma vida ritualizada, com forte espírito de coesão social. Se nossos brios modernos resistem tenazmente a esses estilos de vida, devemos ao menos reconhecer que eles não deixam de ter suas vantagens: proporcionam um senso de pertencimento, uma âncora sem a qual parecemos flutuar em um vazio, sem direção. Talvez uma de nossas tarefas possa ser olhar para o espaço intermediário entre os dois extremos, entre o peso sufocante e a leveza insustentável. Esses extremos devem ser considerados como patológicos, porque sugerem uma impossibilidade de desenvolver um self saudável e promovem dinâmicas sociais desequilibradas, seja por uma atmosfera hiperbárica, levando ao sufocamento ou até mesmo explosões causadas pela entropia, ou por um ambiente hipobárico, com a liberação anômica levando à dissolução de qualquer forma possível de vinculação, trazendo sofrimento ao próprio indivíduo que pretendemos libertar, in- 
Sociologias, Porto Alegre, ano 17, no 39, mai/ago 2015, p. 110-162

divíduos que podem sofrer da malaise de l'infinite ou, na expressão de Kundera, da insustentável leveza do ser.

O que aprendemos de toda esta discussão é que, se a modernidade introduziu a autonomia e autenticidade como novos valores, precisamos primeiro aceitar que sua validade refere-se à sua própria cosmologia não é critério suficiente para julgar outras cosmologias morais. Sob uma perspectiva normativa e crítica, acreditamos ser necessário repensar, de forma menos pré-concebida, noções como tradição e autoridade e, consequentemente, comunidades e pessoas cujas vidas fundam-se nessas fontes e, talvez, até mesmo levantar a questão da eficácia e fragilidade de ter a consciência introspectiva como a única fonte legítima. O que nos é exigido como esforço experimental e um difícil desafio é uma concepção multidimensional e equilibrada de princípios de integração nas sociedades contemporâneas, na qual a racionalidade não precisa ser descartada para que o papel do ritual e do sagrado, e vice-versa, sejam reconhecidos (ROSATI, 2009, p. 50).

Também sabemos que a modernidade tardia pode ser compatível com uma referência normativa que nos leve a aceitar como "modernas" diferentes fontes do self. Nesse caso, o "eu autêntico" precisa ser concebido como apenas uma entre múltiplas escolhas tornadas possíveis pelo ethos pós-secular. Isso sugere a existência recíproca e simultânea de selves autônomos e autênticos, e daqueles heterônomos e tradicionais, como uma consequência natural do reconhecimento de ambos como uma criação coletiva. Paradoxalmente, nessa perspectiva, a legitimação dos princípios da tradição, heteronomia e autoridade tem a mesma fonte que fundamenta os princípios de liberdade, autonomia e autenticidade. Não existe outra base possível, além da criação e consagração coletiva, e esta é a consequência mais radical da sociologia da moral durkheimiana. 


\subsection{Uma terra de múltiplos sagrados e a esperança do pós-secular}

Se aceitarmos como válidas as premissas ontológicas apresentadas na primeira seção, podemos compreender que uma sociedade plural não é apenas um conjunto de diferentes práticas e hábitos culturais, mas, acima de tudo, uma pluralidade de centros, cada um com seus Máximos Postulados Sagrados. E, também como vimos, o sagrado é, por sua própria definição, o que não pode ser negociado, o que está acima de questionamentos. O cenário pode se tornar realmente complicado quando os MPS de diferentes grupos apontam para direções conflitantes, com a existência e a manutenção de um sagrado implicando a destruição de outro. Isso pode se tornar extremamente tenso em contextos em que a fonte legal - válida para todo o grupo que vive no mesmo território -, fundada na autoridade racional-legal, não é reconhecida como tal.

O primeiro passo para pensar uma forma de superar esse problema é supor que a consideração do estado secular como a fonte primordial do sistema legal está baseada numa perspectiva liberal-protestante sobre religiões e sua participação na esfera pública. Ayelet Shachar apresenta o conceito de paradoxo da vulnerabilidade multicultural, que aporta ideias interessantes para esta discussão. Entende-se que este paradoxo resulta de uma política multicultural baseada em um entendimento precário do significado de pertencer a uma religião como muito mais do que uma questão privada, como um conjunto de crenças e práticas que podem ser confinadas a um círculo restrito. Tal política reforça uma hierarquia em que os elementos da cultura liberal permanecem no topo, com total desrespeito aos estilos de vida fundamentalmente diferentes. O único caminho possível para resolver este paradoxo seria promover um verdadeiro equilíbrio entre um esforço para acomodar diferenças e o respeito aos direitos. Por isso, o grande desafio, hoje, é descobrir como construir um "mínimo sagrado comum" ou um "Máximo Postulado Sagrado" compar- 
Sociologias, Porto Alegre, ano 17, no 39, mai/ago 2015, p. 110-162

tilhado (RAPPAPORT, 1999; ROSATI, 2009; 2015) sem o qual uma sociedade pós-secular, com sua pluralidade de sagrados, torna-se impossível.

Concluímos dizendo que não temos respostas claras para todas essas interrogações, mas sugerimos que elas devem ser parte das constelações de problemas discutidos pelas teorias sociais contemporâneas, e que a sociologia da moral deve desempenhar um papel importante em apontar estas dimensões. Do ponto de vista teórico, uma reflexão aprofundada sobre uma categoria controversa como, por exemplo, a de "tradição", pode trazer elementos importantes ao debate, na medida em que consideremos a necessidade de pensar as condições para estabelecer solidariedade entre estranhos e, ao mesmo tempo, evitar o risco de um possível conflito.

Sob um ponto de vista empírico, essas considerações sobre os fundamentos sociais da moralidade e suas consequências na configuração de diferentes tipos de legitimidade e de egos exigem que instituições seculares e moralidades modernas assumam uma atitude menos arrogante em relação àqueles grupos e indivíduos que não desejam se tornar seculares, autônomos ou autênticos. Sob uma perspectiva mais prática, podemos apontar duas fontes possíveis - a secular e a religiosa - para a tolerância, compreendidas como o máximo postulado sagrado necessário ao estabelecimento de uma sociedade pós-secular. Aceitando-se esta dupla fonte, elas podem relacionar-se em um processo de aprendizagem complementar. Isso significa, basicamente, que teorias liberais modernas não são a única fonte possível de valores, como o respeito pela diferença, e que vários esforços empíricos se têm realizado para promover a tolerância, utilizando elementos incorporados em diferentes tradições religiosas, até mesmo naquelas que frequentemente são vistas como a personificação de alguns dos conflitos contemporâneos mais críticos, como o judaísmo e o islamismo.

Por outro lado, o processo complementar também vai em direção contrária, indicando o que as visões liberal-democráticas podem apren- 
Sociologias, Porto Alegre, ano 17, no 39, mai/ago 2015, p. 110-162

der com estilos de vida religiosos; primeiramente, considerando a si mesmas não como verdades óbvias, acima de todas as outras crenças por seu caráter formal, mas simplesmente como outra tradição. Uma tradição que nós, cidadãos ocidentais modernos, valorizamos como nosso bem mais precioso. Isso nos ajuda a reconhecer nossos valores como "sagrados" cuja fundamentação, como qualquer outro sagrado, exige uma vida coletiva e rituais para recriá-los e reforçá-los. Por último, mas não menos importante, isso demanda uma atitude de "humildade moral" como premissa para que o aprendizado complementar se torne um fato e para que o pós-secular se torne um horizonte real. Isso implica, também, um comportamento menos imperialista em relação àqueles que recusam o estilo de vida liberal em nome de crenças religiosas que podemos não possuir mais; e implica, ainda mais, aceitar a possibilidade de que talvez existam coisas que eles possam nos ensinar, enriquecendo e aprofundando nossa própria compreensão sobre o mundo e sobre as formas de viver juntos, de maneira diferente.

\section{Conclusão}

O ponto de partida do presente artigo foi interrogar se o projeto durkheimiano de uma sociologia da moral ainda tinha algo a oferecer ao debate contemporâneo, considerando que nas últimas duas décadas, a moral voltou a ser tema relevante para as ciências sociais (ABEND, 2010; HITLIN; VAISEY, 2010). Nesse processo de (re)estabelecer o campo de pesquisa, diferentes perspectivas estão surgindo, suscitando um questionamento natural sobre a relevância de uma interpretação durkheimiana desse fenômeno (ZIGON, 2007). Estamos com aqueles que acreditam que esta teoria ainda é relevante (ROBBINS, 2007; YAN, 2011) e permanece uma fonte importante de conhecimentos. 
Sociologias, Porto Alegre, ano 17, no 39, mai/ago 2015, p. 110-162

O que sugerimos aqui é que ela pode ser transformada em um programa de pesquisa, desde que a depuremos de suas suposiçóes mais problemáticas e a atualizemos com os avanços recentes no campo da teoria social. Como tentamos demonstrar, a maneira mais produtiva de interpretá-la é pela ótica da sociologia durkheimiana da religião, pois esta conduz a uma profunda renovação de todas as implicações de conceber a moral como um fenômeno social. Ao mesmo tempo, esperamos ter sido capazes de demonstrar como esta leitura nos permite desenvolver uma interpretação crítica sobre alguns dos desafios mais sensíveis do mundo contemporâneo, focando não apenas em seu nível coletivo, mas também naquele que, por décadas, considerou-se ter sido negligenciado por este tipo de sociologia: o papel do indivíduo e o processo de constituição do self.

Para concluir, gostaríamos de destacar que este artigo é apenas um esforço inicial na tentativa de enfatizar a complexidade do fenômeno moral interpretado através das lentes sociológicas, e uma tentativa de persuadir acadêmicos da relevância de se envolverem em debates teóricos e pesquisas empíricas sobre este tema, considerando-o como parte do fazer de cientistas sociais. Afinal, lidar com a moral é lidar com o núcleo da dimensão cultural da vida social, com todas as suas implicações, contradições e desafios.

Massimo Rosati - colaborou com o Centro de Estudos durkheimianos em Oxford desde 2000; dirigiu o Centro de Estudos e Documentação das instituições políticas e religiosas nas sociedades pós-seculares (CSPS) da Universidade de Roma Tor Vergata.

Raquel Weiss - é professora adjunta do departamento de Sociologia da UFRGS, e faz parte do NER - Núcleo de Estudos da Religião. Pesquisadora associada ao British Centre for Durkheimian Studies, da Oxford University e diretora do Centro Brasileiro de Estudos Durkheimianos. $\$ weiss.raquel@gmail.com 
Sociologias, Porto Alegre, ano 17, no 39, mai/ago 2015, p. 110-162

\section{Referências}

1. ABEND, Gabriel. What`s New and What`s Old about the New Sociology of Morality. In: HITLIN; VAISEY (Orgs.). Handbook of the Sociology of Morality. New York: Springer, 2010. P. 561-584.

2. ALEXANDER, Jeffrey. C.. Durkheimian Sociology: Cultural Studies. [S.I.]: Cambridge University Press, 1990.

3. ALEXANDER, Jeffrey C.; GIESEN, Bernhard; MAST, Jason L.. Social Performance: Symbolic Action, Cultural Pragmatics, and Ritual. [S.I.]: Cambridge University Press, 2006.

4. ALEXANDER, Jeffrey C.. Performance and Power. [S.I.]: John Wiley \& Sons, 2013.

5. BELLAH, Robert N.. Morale, religion et société dans l'øe uvre durkheimienne. In: Archives de sciences sociales des religions, v. 35, n. 69, mar. 1990, p. 9-25.

6. CARDI, François et al. Durkheim, sociologue de l'éducation. Journées d'étude 15-16 octobre 1992. Paris: L'Harmattan, INRP, 1993.

7. COLLINS, Randall. Interaction Ritual Chains. [S.I.]: Princeton University Press, 2014.

8. DURKHEIM, Émile. De l'irreligion de l'avenir. In: Revue Philosophique, v. 23, 1887a., p. 299-311.

9. DURKHEIM, Émile. La Science Positive de la Morale en Allemagne. In: Revue philosophique, 1887c; Reproduzido em Textes 2, v. 24, p. 24: 33-58, 113-42, 275-84., 1887b.

10. DURKHEIM, Émile. Quid Secondatus politicae scientiae instituendae contulerit. Bourdeaux: Gounouilhou, 1892.

11. DURKHEIM, Émile. De la Division du Travail Social - étude sur l'organization des sociétés supériueres. [S.I.]: Felix Alcan, 1893.

12. DURKHEIM, Émile. Les règles de la méthode sociologique. Paris: F. Alcan, 1895.

13. DURKHEIM, Émile. Le suicide étude de sociologie. Paris: F. Alcan, 1897. (Bibliothèque de philosophie contemporaine).

14. DURKHEIM, Émile. L'Individualisme et les Intellectuels. In: Revue Bleue, v. 10e tome, 35 année, 1898, p. 7-13.

15. DURKHEIM, Émile. Sur la Séparation des Églises et de l'état [contribuição à discussão]. In: Libres Entretiens de L’Union pour la Vérité, v. 1, 1905, p. 369-71, 496-500. 
Sociologias, Porto Alegre, ano 17, no 39, mai/ago 2015, p. 110-162

16. DURKHEIM, Émile. Les formes élémentaires de la vie religieuse: le système totémique en Australie. [S.I.]: F. Alcan (Paris), 1912. Disponível em: < http://gallica.bnf.fr/ark:/12148/bpt6k744652>. Acesso em: 17 nov. 2010.

17. DURKHEIM, Émile. Le Problème Religieux et la Dualité de la Nature Humaine. In: Bulletin de la Sociéte Française de Philosophie, v. 13, 1913, p. 63-100.

18. DURKHEIM, Émile. Le Dualisme de la Nature Humaine et ses Conditions Sociales. In; Scientia, v. 15, 1914, p. 206-221.

19. DURKHEIM, Émile. Ideal Moral, Conscience Collective et Forces Religieuses [Anotações de curso por Georges Davy]. In: LUKES, Steven. Émile Durkheim, an intellectual biography [tese de doutorado] Oxford, 1968. Localizada na Bodleia Library, Oxford, 2 vols. Sorbonne, Paris, set. 1908. p. 246-260.

20. DURKHEIM, Émile. Introduction à la Morale. In: Revue Philosophique, v. 89, 1920, p. 79-97.

21. DURKHEIM, Émile. Sociologie et Philosophie. Paris: Fékix Alcan, 1924.

22. DURKHEIM, Émile. L'éducation morale. Paris: F. Alcan, 1925. (Travaux de I'Année sociologique).

23. DURKHEIM, Émile. L'Enseignement de la Morale à L'École Primaire. In: Revue Française de Sociologie, v. XXXIII, 1992, p. 609-23.

24. DURKHEIM, Émile. O Ensino da Moral na Escola Primária. In: Novos Estudos Cebrap, v. 78, 2007, p. 61-75.

25. DURKHEIM, Émile; ROSATI, Massimo. Le forme elementari della vita religiosa: il sistemo totemico in Australia. Roma: Meltemi, 2005.

26. DURKHEIM, Émile; WILSON, Everett K.; SCHNURER, Herman. Moral education: a study in the theory and application of the sociology of education. New York London: Free Press; Collier Macmillan, 1973.

27. FERRARA, Alessandro. Reflective Authenticity: Rethinking the Project of Modernity. [S.I.]: Routledge, 2002.

28. FERRARA, Alessandro. The Force of the Example: Explorations in the Paradigm of Judgment. New York: Columbia University Press, 2008.

29. HALL, Robert T. Émile Durkheim: ethics and the sociology of morals. New York; London: Greenwood, 1987.

30. HITLIN, Steven; VAISEY, Stephen. Back to the Future. In: HITLIN, Steven; VAISEY, Stephen (Org.). Handbook of the Sociology of Morality. New York: Springer, 2010. P. 3-14.

31. ISAMBERT-JAMATI, Viviane. Pédagogie et sociologie chez Jean-Claude Forquin. In; Revue française de pédagogie, v. 135, n. 1, 2001, p. 125-130.

http://dx.doi.org/10.1590/15174522-017003904 
Sociologias, Porto Alegre, ano 17, no 39, mai/ago 2015, p. 110-162

32. JONES, S. G. Stedman. Charles Renouvier and Émile Durkheim: Les Règles de La Méthode Sociologique. In: Sociological Perspectives, v. 38, n. 1, 1995, p. $27-40$.

33. JONES, Susan Stedman. Durkheim reconsidered. Cambridge: Polity, 2001.

34. LACAPRA, Dominick. Émile Durkheim: sociologist and philosopher. Ithaca [N.Y.: Cornell University Press, 1972.

35. MILLER, William Watts. Durkheim, Morals and Modernity. London/Montreal: UCL Press/McGill-Queen's University Press, 1996.

36. MILLER, William Watts. Dynamogénique and Élementaire. In: Durkheim Studies, v. 11, 2005, p. 18-32.

37. MILLER, William Watts. Investigando o projeto de Durkheim para a constituição de uma Ciência Social. In: MASSELLA, ALEXANDRE et al. (Org.).. Durkheim: 150 Anos. São Paulo: Argvumentvn, 2009. P. 39-68.

38. MILLER, William Watts. Durkheim's Montesquieu. The British Journal of Sociology, v. 44, n. 4, dezembro 1993, p. 693-712.

39. PICKERING, W. S. F. Durkheim's Sociology of Religion - Themes and Theories. Cambridge: James Clarke \& Co., 2009.

40. PICKERING, W. S. F.; ROSATI, Massimo. Suffering and evil: the Durkheimian legacy in commemoration of the 90th anniversary of Durkheim's death. New York: Berghahn Books, 2008.

41. RAPPAPORT, Roy A. Ritual and Religion in the Making of Humanity. [S.I.]: Cambridge University Press, 1999.

42. ROBBINS, Joel. Continuity Thinking and the Problem of Christian Culture Belief, Time and the Anthropology of Christianity. In: Current Anthropology, v. 48, n. 1,2007 , p. $5-38$.

43. ROSATI, Massimo. Ritual and the sacred: a neo-Durkheimian analysis of politics, religion and the self. Farnham: Ashgate, 2009.

44. ROSATI, Massimo. The Making of a Postsecular Society: A Durkheimian Approach to Memory, Pluralism and Religion in Turkey. [S.I.]: Ashgate Publishing, Ltd., 2015.

45. SELIGMAN, Adam B. Modernity's Wager: Authority, the Self, and Transcendence. [S.I.]: Princeton University Press, 2009.

46. SELIGMAN, Adam B. et al. Ritual and Its Consequences: An Essay on the Limits of Sincerity: An Essay on the Limits of Sincerity. [S.I.]: Oxford University Press, 2008. 
Sociologias, Porto Alegre, ano 17, no 39, mai/ago 2015, p. 110-162

47. SELIGMAN, Adam B.; WELLER, Robert P. Rethinking Pluralism: Ritual, Experience, and Ambiguity. [S.I.]: Oxford University Press, 2012.

48. SHILS, Edward. Center and Periphery: Essays in Macrosociology. [S.I.]: University of Chicago Press, 1975.

49. TAYLOR, Charles. Varieties of Religion Today: William James Revisited. [S.I.]: Harvard University Press, 2003.

50. TIRYAKIAN, Edward A. For Durkheim: essays in historical and cultural sociology. Burlington, VT: Ashgate, 2009. (Rethinking classical sociology).

51. WEISS, Raquel. A Concepção de Educação de Émile Durkheim como Chave para a Passagem e Entre Positivo e Normativo. In: MASSELLA, ALEXANDRE et al. (Org.).. Durkheim: 150 Anos. São Paulo: Argvumentvn, 2009. P. 169-189.

52. WEISS, Raquel. Do mundano ao sagrado: o papel da efervescênciana teoria moral durkheimiana. In: Horizontes Antropológicos, v. 19, 2013a, p. 395 - 421.

53. WEISS, Raquel. Efervescência, dinamogenia e a ontogênese social do sagrado. In: Mana, v. 19, n. 1, abr. 2013b, p. 157-179.

54. WEISS, Raquel. Émile Dukheim e a Ciência da Moral. São Paulo: [s.n.], 2006.

55. WEISS, Raquel. Émile Durkheim e a Fundamentação Social da Moralidade. 2011. Ph. Thesis - Universidade de São Paulo, São Paulo, 2011.

56. WEISS, Raquel. From Ideas to Ideals: effervescence as the key to understanding morality. In: Durkheim Studies, v. 18, 2012, p. 81-97.

57. WEISS, Raquel; PERES, Paulo. Beyond the Altruism-Egoism Dichotomy: a new Typology to Capture Morality as a Complex Phenomenon. In: JEFFRIES, VIincent (Org.). Handbook of Altruism, Morality and Social Solidarity. New York: Palgrave Macmilan, 2014. .

58. YAN, Yunxiang. How far away can we move from Durkheim? - Reflections on the new anthropology of morality. In: Anthropology of thi Century, v. 2, 2011. Disponível em: <http://aotcpress.com/articles/move-durkheim-reflectionsanthropology-morality/>. Acesso em: 17 jan. 2015.

59. ZIGON, Jarrett. Moral breakdown and the ethical demand a theoretical framework for an anthropology of moralities. In: Anthropological Theory, v. 7, n. 2, 1 jun. 2007, p. 131-150.

Recebido em: 22/01/2015

Aceite Final: 05/03/2015

http://dx.doi.org/10.1590/15174522-017003904 